\title{
Entre morcegos e beija-flores: reflexões críticas sobre a jurisdição constitucional no Brasil
}

\author{
Between bats and hummingbirds: \\ critical reflections on constitutional jurisdiction in Brazil
}

\author{
MAREN GUIMARÃES TABORDA ${ }^{1}$ \\ Professora de História do Direito e de Direito Municipal na Fundação Ministério Público (FMP-RS) e \\ e Professora Adjunta de Direito Constitucional na PUCRS (licenciada)
}

\begin{abstract}
RESUMO: Trata o presente ensaio das particularidades da Jurisdição Constitucional no Brasil, analisada criticamente do ponto de vista da relação entre Estado de Direito e Jurisdição e das suas finalidades. Afirma-se, também, a necessidade e utilidade de compreender a Jurisdição Administrativa como parte integrante das medidas técnicas de garantia da Constituição, bem como de apontar as contradições e dificuldades da adoção de um sistema híbrido de controle de constitucionalidade. Discute-se, por conseguinte, a inadequação prática e teórica de se utilizarem instrumentos processuais de controle difuso em controle concentrado de constitucionalidade.
\end{abstract}

Palavras-chave: Jurisdição constitucional; Técnicas de controle de constitucionalidade; Controle abstrato; Recurso extraordinário.

\begin{abstract}
This paper is about the peculiarities of Constitutional Jurisdiction in Brazil, critically analyzed in terms of the relationship between rule of law and Jurisdiction and its purposes. It is also stated the need and the value to understand and to use the administrative jurisdiction as one of the technical ways to ensure the Constitution as well as to point out the contradictions and difficulties of adopting a hybrid system of judicial review. It is argued, therefore, the theoretical and practical inadequacy of using procedural instruments of different systems of judicial review.
\end{abstract}

Keywords: Constitutional jurisdiction; Technical forms on the judicial review; Abstract control; "Extraordinary appeal".

\section{INTRODUÇÃO}

O estudo da Jurisdição Constitucional, em sede de Teoria do Direito, é um dos mais fascinantes e complexos, porque envolve conceitos e noções que permeiam todo o sistema jurídico, permitindo a mais ampla discussão sobre temas como 'conceito de Jurisdição', 'teoria das funções estatais', 'ação e direito subjetivo', 'efeitos das sentenças', 'controle jurisdicional da Administração', 'garantias dos Direitos Fundamentais', 'técnicas de processo', etc. No entanto, nos manuais de estudo, obras de doutrina e nos conteúdos programáticos das disciplinas que têm o direito constitucional por objeto, tal complexidade não é deveras ressaltada e o estudo, com honrosas exceções, é feito de forma fragmentária e estanque, não se apresentando ao estudioso (estudante) o sistema de verificação de constitucionalidade dos atos normativos no Brasil como o resultado de escolha de modelos históricos diversos e até mesmo incompatíveis.

Assim, parte-se do pressuposto de que há acordo sobre o que se entende por 'função jurisdicional' na teoria das funções estatais²; que não há jurisdição administrativa no País e se misturam, na praxis judiciária, as técnicas de controle abstrato e as de controle concreto de constitucionalidade, sem falar nas ditas "ações constitucionais", que são estudadas e discutidas sem fazer-se qualquer vínculo com o controle jurisdicional da Administração. Nada mais perigoso para a formação dos juristas, pois o 'cipoal' teórico ao qual fica delimitado o seu pensar acaba por ter consequências práticas que não podem ser minimizadas. Considere-se, por exemplo, a possibilidade de ações diretas de inconstitucionalidade de leis municipais e estaduais, ou mesmo, a exigência de preliminar formal de repercussão geral nos recursos extraordinários em controle abstrato de tais leis. Essas hipóteses, fruto do hibridismo do sistema de controle de constitucionalidade típico do Brasil ${ }^{3}$ acabam por produzir contradições insanáveis ou aporias no plano teórico e no plano prático e as respostas dadas pelo STF contribuem, muitas vezes, para aprofundá-las.

Assumindo que é útil e necessário compreender sistemática e criticamente a Jurisdição Constitucional 
no Brasil, a finalidade deste estudo é explicitar a natureza e função da Jurisdição Constitucional no marco da Teoria da Constituição e refletir sobre as vicissitudes e particularidades de um sistema híbrido de controle de constitucionalidade, sem a pretensão de esgotar o assunto.

Dado que o Direito, experiência metodologicamente qualificada, é também a arte que faz prevalecer o fundamental critério de valoração que é a racionalidade conjugada com a igualdade, é tarefa do jurista, atento aos dados da realidade, fazer o juízo crítico do Direito, conjugando os diferentes fatos normativos entre si e harmonizando-os com as exigências da justiça e utilidade presentes nos casos concretos. Por isso, este ensaio trata de inventariar contradições, virtudes, vícios do sistema de controle de constitucionalidade brasileiro, apontando, aqui e ali, "quando se quis fazer um beija-flor e se fez um morcego". Para tais finalidades, o estudo foi dividido em duas partes: a primeira explicita a pré-compreensão subjacente no que diz respeito à Jurisdição e à função e natureza da Jurisdição Constitucional, de modo geral (I). A segunda parte é específica sobre as peculiaridades da fiscalização de constitucionalidade no Brasil e aborda as medidas técnicas de garantia da Constituição, bem como as hipóteses problemáticas do nosso sistema de controle de constitucionalidade (II).

\section{JURISDIÇÃO E ESTADO DE DIREITO}

Para a compreensão sistemática da Jurisdição Constitucional no Brasil, é preciso, primeiramente, fazer uma digressão (ainda que sintética), do que se entende materialmente por Jurisdição (1.1), e da natureza e função da Jurisdição Constitucional (2.2), uma vez que , no sistema brasileiro, só pela via jurisdicional se pode garantir a conformidade à Constituição, seja ao modo preventivo (evitando a produção de atos irregulares), seja ao modo repressivo (reação contra atos irregulares produzidos), em face da adoção, desde a primeira Constituição republicana, do princípio da Jurisdição única ${ }^{4}$.

\subsection{A Jurisdição como função estatal}

No século XX, a Escola Normativista (Kelsen e Merkl), afirmou ser possível distinguir somente duas funções estatais, do ponto de vista material (ainda que tal distinção não seja absoluta, por força do "princípio dinâmico"): toda criação é execução, toda execução é criação, com as duas exceções-limite: a norma fundamental e a execução de sentença. Assim, legislação é a atividade de criação de normas gerais, praticada preponderantemente pelo Legislativo, e
Execução (latu sensu), a aplicação das normas gerais a um caso concreto (criação ou constituição da "norma concreta"), praticada preponderantemente ou pelo Executivo, via atos administrativos, ou pelo Judiciário, via atos judiciais.

De um ponto de vista material, todos os atos que aparecem nessa estrutura escalonada como 'formuladores de direito' são condicionantes; os que aparecem como 'execução do direito' são condicionados. No ápice da pirâmide hierárquica, têm-se atos de pura competência (só se manifesta o aspecto formulador); na base, atos de pura execução, ou obrigação. Vista a estrutura de cima para baixo, os atos intermediários apresentam caráter de formuladores (leis, decretos, sentenças judiciais); ao contrário, de baixo para cima, tais atos intermediários apresentam duplo caráter - formulação e execução ${ }^{5}$.

Tal concepção tem sido aceita quase sem reservas pelos constitucionalistas portugueses e brasileiros. A determinação dos campos de aplicação respectivos dos regimes jurídicos dos atos administrativos e dos atos jurisdicionais - em si mesmo muito diferentes - não pode ser feita somente tendo-se em vista critérios formais, pois os órgãos jurisdicionais, por vezes, exercem função puramente administrativa que escapam ao regime dos atos jurisdicionais. Por esta razão, impõem-se uma definição e um critério material para o ato jurisdicional, o que não é assim tão simples, na medida em que qualquer tentativa de defini-lo esbarra em questões de fundo que não podem ser desconhecidas. A primeira controvérsia concerne à consideração de jurisdição como função estatal, reduzindo a primeira e mais fundamental experiência jurídica a uma abstração que termina por estreitar uma visão unitária do ordenamento jurídico. A segunda observação a ser feita diz respeito a uma concepção geral das funções estatais através dos processos pelos quais elas se desenvolvem no tempo processo legislativo, processo jurisdicional e processo administrativo - de modo que este desempenha em relação à função, o papel de forma externa, no sentido de sua manifestação sensível.

A processualística tradicional, a seu turno, conceitua Jurisdição como função estatal, partindo da configuração moderna do Estado, que monopolizou e centralizou a produção e aplicação do Direito ${ }^{6}$. Para $\mathrm{Satta}^{7}$, mesmo que seja correto do ponto de vista histórico conceber a Jurisdição como poder do Estado (emanação de sua soberania frente a todas as jurisdições particulares), afirmar que a mesma, juntamente com a Administração e a Legislação, são exaustivas de toda a complexidade e poder do Estado é um grave erro ou, no mínimo, uma visão parcial, pois parte de uma premissa 
moderna, qual seja, de que o Estado é uma 'pessoa' ou um 'ente'. Por isso, Satta assevera ser Jurisdição a concreção da ordem jurídica ou afirmação da ordem jurídica no caso concreto, de modo que este resta subjetivado no mecanismo da Jurisdição: um sujeito que postula a eficácia do ordenamento em relação a outro sujeito ${ }^{8}$.

A postulação pelo ordenamento comporta uma fundamental consequência, que gera o que se chama 'processo': postular o ordenamento significa postular o juízo, e o juízo é essencialmente processo (processus iudicii), actus trium personarum, em cujo desenvolvimento estão vinculadas as partes e o juiz. Ação, jurisdição e processo são três faces de uma única realidade9 ${ }^{9}$. Daí a Jurisdição ser entendida como um poder (manifestação de soberania) e uma atividade (movimentação do juiz no processo, exercendo o poder e cumprindo a função que a lei lhe comete), falandose em "atuação do direito", "composição da lide", "realização da sanção", "substituição da atividade privada", pondo-se em evidência ora a garantia exterior da função (imparcialidade do juiz e contraditório), ora a natureza do interesse, ora o procedimento lógico que precede o ato (vínculo a norma legal ou discricionariedade) ou a prevalência do juízo sobre a vontade.

Consoante Pontes de Miranda $^{10}$, o processo tem uma função pacificadora mediata, pois imediata é a "função realizadora do direito objetivo". Frente a isso, reconhecida a diferença entre ação (a actio romana, que é material), pretensão (atuação do direito subjetivo), direitos subjetivos (localização, individuação do direito objetivo) e remédios jurídicos processuais ("ação" processual, que corresponde ao exercício da pretensão à tutela jurídica - pretensão de direito público), o Estado, através de seus órgãos, ao prestar a justiça, emite a sentença, que é um dos modos de extinguir-se a relação jurídica processual ou a "dívida jurisdicional do Estado"11.

Se a tripartição das funções do Estado exprime o princípio político de que a organização da sociedade se articula em vários momentos - manifestação em termos gerais (lei), concreta ação em que aquela vontade geralmente expressa constitui a razão e a legitimidade (administração) e a afirmação da vontade geral nos casos concretos (sentença) - a estes correspondem, respectivamente, a legislação, a administração e a jurisdição. Por outro lado, aproximados os conceitos de função, processo e ato, o processo passa a ser "uma via jurídica pela qual se procura garantir uma correta formação e expressão de uma vontade funcional" ${ }^{12}$, de forma que a função - processo legislativo - teria por finalidade a prática de atos de criação do Direito; as funções e processos jurisdicionais e administrativos, a aplicação do Direito, através de atos jurisdicionais e administrativos.

No entanto, como perspectiva política e realização histórica, a organização da sociedade é infinitamente mais complexa, basta pensar em todos os fenômenos que ocorrem em nome do direito privado, como na jurisdição voluntária (administração pública do direito privado ${ }^{13}$. Sendo assim, admite-se geralmente, em sentido material, que o ato jurisdicional é um ato de estrutura complexa, em que aparecem, sucessivamente, a) uma pretensão diante de um juiz; b) uma constatação, feita por um juiz, de conformidade de uma situação de fato a uma regra de direito e c) uma decisão do juiz em consequência da constatação por ele feita ${ }^{14}$.

A consequência dessas afirmações é que a função jurisdicional se deixa qualificar como execução (da lei ou do ordenamento) e, nisto, aproxima-se da administração. Com efeito, os juspublicistas, na esteira de Montesquieu, apresentam e estudam a função jurisdicional como uma manifestação do poder estatal, mas não estão de acordo no que diz respeito à consideração da mesma somente como uma atividade executiva stricto sensu, porque isto conduziria a admitir a existência de duas funções (legislativa e executiva, com seus ramos particulares: Administração e Justiça) e acabaria por reduzir os poderes estatais a dois poderes primordiais.

Ressalte-se, ainda, por oportuno, que o juiz, ao simplesmente aplicar a lei ou preparar as condições de sua execução, opera de forma muito semelhante aos administradores, fazendo com que a função jurisdicional se refira ao Poder Executivo e entre na esfera do conceito geral deste Poder. Assim, a Jurisdição entra na definição do que seja função legislativa e função executiva, conforme crie direito jurisprudencial ou aplique direito legal, respectivamente. Persiste, contudo, o problema de distinguir uma função jurisdicional propriamente dita, que não se susbsuma em Administração. $\mathrm{O}$ resultado leva à conclusão de que as diferenças entre Jurisdição e Administração são de ordem externa e formal (relativas aos fins a perseguir, aos procedimentos de execução, à natureza psicológica das operações e às circunstâncias nas quais são chamadas a intervir) e não de ordem material. As razões pelas quais se separam, nos Estados modernos, as funções jurisdicionais e administrativas são de ordem política - prover os cidadãos de juízes que estatuam com independência, repartir competências (estabelecer um conjunto de regras particulares e de garantias protetoras para a organização dos tribunais e para o funcionamento de sua atividade) -, isto é, de fins e de formas, fazendo com que, em Direito, não exista 
"em sentido material, uma função jurisdicional distinta, senão que existem somente formas jurisdicionais e uma via jurisdicional distinta das formas e da via administrativas" 15 .

Considerando as funções jurisdicionais e administrativas espécies do gênero 'execução' - ambas determinam ou definem situações jurídicas individuais - e examinando-se a finalidade e conteúdo de cada uma delas, Seabra Fagundes, assumindo que é possível uma distinção material, afirma que "o momento em que é chamada a intervir a função jurisdicional, o modo e a finalidade, porque interfere no processo realizador do direito, é que lhe dão os caracteres diferentes"16. O momento do exercício da função jurisdicional é o de uma situação contenciosa surgida no processo de realização do direito; o modo através do qual se alcança sua finalidade é a "interpretação definitiva do direito controvertido" e a finalidade de seu exercício, remover o conflito ou promover "o trancamento da situação contenciosa"17. Sendo assim, o ato jurisdicional - a sentença - é o ato "através do qual o Estado define e determina situações jurídicas individuais, com o fim de remover, pela definitiva interpretação do direito, conflito surgido a propósito de sua aplicação" 18 , e ato administrativo, "aquêles através dos quais o Estado determina situações jurídicas individuais e concorre para sua formação"19.

Por fim, e o mais importante, o ato jurisdicional de composição da lide (sentença de mérito) adquire autoridade de coisa julgada, isto é, seus efeitos tornamse imutáveis. As decisões administrativas, ao contrário, apenas podem precluir no âmbito da administração, não admitindo mais recurso administrativo, mas estão sujeitas, sem exceção, ao reexame pelo Judiciário, dependendo da forma que esse controle assuma em cada Constituição particular ${ }^{20}$. Por esta razão é que Pontes de Miranda ${ }^{21}$ assegura não haver, no sistema brasileiro, decisão administrativa com eficácia de coisa julgada, mesmo que à Administração, em certas circunstâncias, seja conferido pela Constituição e pelas leis o poder de decidir controvérsias ${ }^{22}$.

Em síntese, se à Jurisdição cabe resolver, com força de coisa julgada, controvérsia surgida a propósito da aplicação do Direito, a ela é atribuída a competência de fiscalização de constitucionalidade e de legalidade dos atos de poder. Em sentido amplo, legalidade pode ser traduzida "conformidade do poder com o Direito a que deve obediência, com o Direito positivo ou decretado pelo Estado"23. Já em sentido estrito, legalidade é conformidade ou compatibilidade com a lei ordinária. Constitucionalidade é conformidade à Constituição. Assim, negativamente, pode-se falar em ilegalidade e em inconstitucionalidade como violações das normas jurídicas por atos do poder. Pecisamente porque as normas podem não ser cumpridas, os meios institucionais de garantia de observância (fiscalização em sentido estrito) é que acabam por assegurar a efetividade global da Constituição.

Dado que a fiscalização (o controle) de constitucionalidade ou de legalidade pode assumir diversas modalidades (respeitantes ao objeto, aos órgãos, aos interesses no processo e à forma processual), é preciso reconhecer que sempre que a fiscalização seja feita pelo Poder Judiciário (por órgãos jurisdicionais comuns ou especiais), com força de coisa julgada e por via de ação, se está diante da Jurisdição Constitucional e da Jurisdição Administrativa, respectivamente. Assim, mesmo que não exista no Brasil Jurisdição Administrativa em sentido estrito (aos moldes do contencioso Francês) e tampouco Tribunal Constitucional, no plano material, a atividade de controle exercida pelo Judiciário sempre está circunscrita ao conceito de 'Jurisdição'. Daí, mais clara fica a relação entre a Jurisdição Constitucional e a Jurisdição Administrativa, na medida em que a última, ao fazer a verificação da legalidade da execução, acaba por verificar, indiretamente, a conformidade à Constituição.

Por esta razão, pode-se chamar as ditas 'ações constitucionais' de instrumentos de controle jurisdicional da Administração (com exceção do Mandado de Injunção), uma vez que tais instrumentos precederam, historicamente, ao controle judicial formal de constitucionalidade ${ }^{24}$, bem como ao controle de constitucionalidade feito por Tribunal Constitucional surgido na Europa do século XX, após a barbárie nazista. Assim, no plano material, falar em controle judicial de constitucionalidade é o mesmo que falar em Jurisdição Constitucional e, por isso, cabe fazer uma apreciação mais minudente sobre a natureza e função da Jurisdição Constitucional.

\subsection{Natureza e Função da Jurisdição Constitucional}

Foi Kelsen ${ }^{25}$ quem pôs as bases teóricas para a compreensão adequada da natureza e função da Jurisdição (ou Justiça) Constitucional. Segundo ele, a Jurisdição Constitucional é garantia da Constituição, que põe, ao menos, duas questões: uma teórica, qual seja saber-se a natureza jurídica dessa garantia e outra, prática, isto é, verificar os melhores meios para concretizá-la. Na perspectiva teórica, é possível afirmar ser a Jurisdição Constitucional um elemento do sistema de medidas técnicas que têm por fim garantire regular o exercício das funções estatais, uma vez que, na estrutura escalonada da ordem jurídica, cada uma das funções são, ao mesmo tempo, atos de criação 
e aplicação do Direito, ou etapas da formação da vontade coletiva (ordem internacional - constituição - lei - regulamento - sentença - ato administrativo - execução material). Segundo isso, constituição, leis e decretos são normas gerais; ato administrativo e sentença são normas individuais.

Nestas condições, a tarefa da Jurisdição Constitucional é verificar a conformidade à Constituição; a da Jurisdição Administrativa, verificar a legalidade da execução. Daí ser fundamental a distinção entre Constituição em sentido formal - princípio supremo determinante da ordem jurídica - e, em sentido material - norma que rege a elaboração das leis e das normas gerais de execução (atividade dos órgãos administrativos e jurisdicionais). Em síntese, para Kelsen, a garantia específica da Constituição se dá pela Jurisdição Constitucional e a garantia de legalidade da execução, pela Jurisdição Administrativa e, neste caso, a inconstitucionalidade é indireta, pois, de acordo com o Princípio formal da Legalidade da execução, só pode haver ato de execução com base em uma lei ${ }^{26}$. Quando, no entanto, o ato administrativo (concretização do direito individual) é praticado diretamente com base na Constituição, "traz diretamente em si o caráter de constitucionalidade ou inconstitucionalidade" e, neste caso, "a jurisdição constitucional, enquanto controle de atos administrativos, significa uma jurisdição administrativa especial, diferenciando-se da jurisdição administrativa geral apenas porque controla externamente a constitucionalidade do ato, e não, sua simples conformidade à lei" 27 .

No que diz respeito às modalidades de fiscalização de constitucionalidade, são bastante diversas. Preventivo é o controle que evita a produção de atos irregulares; já as garantias repressivas reagem contra ato irregular produzido. No que tange aos órgãos (sujeitos da fiscalização), podem ser comuns (cujas competências são diversas das de garantia), tais como o Parlamento, os tribunais comuns, judiciais ou administrativos, o Presidente da República, o Rei, etc., ou, ainda, especiais, aqueles criados ex professo para isso (júris, comissões, conselhos, tribunais constitucionais), que, muitas vezes, têm competências complementares. De outra parte, fiscalização difusa é aquela que compete a órgãos dispersos, e concentrada, a que compete a um só órgão ou a um número reduzido de órgãos. Assim, segundo Jorge Miranda, a fiscalização jurisdicional pode "tanto ser difusa como concentrada; a fiscalização política é (tende a ser) sempre concentrada; a fiscalização administrativa (a existir) é sempre difusa" ${ }^{28}$.

Ademais de tais modos de organização, a Jurisdição Constitucional (ou fiscalização de constitucionalidade) é concreta quando ocorre por ocasião da aplicação de atos normativos a casos concretos, sejam eles lides ou providências administrativas; é abstrata ou em tese, quando incide sobre comportamentos dos órgãos do poder público ou se refere às normas em si mesmas consideradas. Neste particular, elucidativas as palavras de Jorge Miranda, verbis: "A fiscalização concreta redunda em garantia da constitucionalidade no espaço comunitário quotidiano. A fiscalização abstracta inserese no equilíbrio global dos órgãos do Estado e pode ser entendida como expressão qualificada de um pouvoir d'empêcher"'29.

Por derradeiro, no tocante aos critérios processuais de controle, que dizem respeito aos interesses subjacentes envolvidos no processo, a fiscalização pode ser objetiva quando tem em vista a preservação ou a restauração da ordem jurídica; e subjetiva, quando se prende ao interesse pessoal de alguém. Quanto ao objeto do processo, a fiscalização pode ser incidental (a finalidade do processo não é verificação de constitucionalidade: ela se dá em qualquer processo) ou principal (a garantia de constitucionalidade é o fim principal e único) no qual a constitucionalidade é o objeto, a causa da ação. Já no respeitante à forma processual, há fiscalização por via de exceção (iniciativa enxertada em um processo em curso), ou por via de ação (direito de poder desencadear um processo com vista a determinado fim). Sendo assim, utilizando-se tais critérios, pode-se afirmar que o controle de constitucionalidade difuso é concreto, predominantemente subjetivo e incidental. O controle concentrado é, via de regra, abstrato, objetivo e principal.

Quaisquer que sejam os modos de organizar-se a Jurisdição Constitucional, o certo é que a anulação do ato inconstitucional é o que representa a principal e mais eficaz garantia da Constituição. Contudo, tal resultado encerra um problema técnico, pois anular a lei é estabelecer uma regra geral e, portanto, o tribunal que anula uma lei funciona como um legislador negativo. Isso explica o teor do art. 52, X, da Constituição da República Federativa do Brasil, segundo o qual o Senado, através de resolução, deve suspender a execução de lei declarada inconstitucional pelo STF.

A Jurisdição Constitucional, ao ser uma afirmação do princípio da divisão (separação) de poderes, ou como diz Kelsen, elemento do sistema de medidas técnicas que têm por fim garantir e regular o exercício das funções estatais, acaba por ser um dos supostos do Estado Democrático de Direito, porquanto serve de contrapeso efetivo entre o Poder Executivo "cada vez mais hegemônico" e o Poder Legislativo cada vez mais "ambíguo em sua estrutura e funcionamento" ${ }^{2}$. 
É, igualmente, o suposto fundamental para a preservação dos direitos fundamentais, principalmente os de liberdade. Isso se deve ao fato de a teoria da separação dos poderes e seu "sistema de freios e contrapesos" ter sido, inicialmente, uma proclamação política que despertou "a atenção para as violações constitucionais e os remédios para a atuação ilegal da autoridade pública", para acabar sendo consagrada constitucionalmente como mecanismo de defesa das liberdades individuais e do abuso de poder ${ }^{31}$.

O objetivo fundamental da Jurisdição Constitucional é, então, a defesa jurídica da liberdade, isto é, uma instituição diferenciada e reforçada, capaz de realizar de forma efetiva - concretizar - os direitos fundamentais. Essa diferenciação se dá pela sua estrutura e pelos seus efeitos, radicalmente diferentes dos que se perseguem nos juízos ordinários ${ }^{32}$. As normas e os princípios constitucionais ficam, então, garantidos por um processo especial ${ }^{33}$, e a questão de saber se a jurisdição constitucional é controle político, atividade legislativa ou paralegislativa, uma nova e especial função, ou, ainda, preferentemente função jurisdicional, está em aberto $^{34}$.

O passo decisivo para que a Justiça Constitucional se configurasse como instituição capaz de tutelar efetivamente os direitos fundamentais em termos modernos foi dado pela legislação alemã - Lei de 12 de março de 1951 - ao instituir o Tribunal Constitucional Federal e introduzir o recurso constitucional direto (Verfassungbeschwerde) $^{35}$. A partir daí, os publicistas contemporâneos, principalmente os influenciados pela elaboração teórica da jurisprudência daquele tribunal, são unânimes em afirmar a jurisdição constitucional como expressão da ideia de Estado de Direito, que exige um controle jurisdicional independente da atuação das autoridades públicas ${ }^{36}$. A doutrina constitucional alemã e os comentários à Lei Fundamental preservaram a ideia do Tribunal Constitucional como "órgão constitucional dotado da mais alta autoridade" e "Guardião da Constituição" 37 . Por isso, Hesse afirma que, no quadro da ordem democrática, a Constituição efetua um refreamento e controle de poder e um certo equilíbrio das forças políticas, através do controle judicial de "todos os poderes estatais pela jurisdição constitucional, dotada com ampla competência na Lei Fundamental"38.

Assim, a Jurisdição Constitucional pela qual o Poder Judiciário está intercalado no equilíbrio dos poderes estatais, "dá seu cunho não só à ordem das funções estatais, mas à ordem constitucional total", pois influencia a colaboração dos órgãos estatais, "contribui para a conservação da coexistência de forças políticas diferentes, aproximadamente equilibradas", sendo, simultaneamente, a condição fundamental de eficácia da Constituição ${ }^{39}$.
$\mathrm{Na}$ perspectiva histórica, constituíram-se, pelo menos, três sistemas de controle de constitucionalidade ou de jurisdição constitucional: puros, especiais ou mistos. O controle puramente jurisdicional é o de tipo norte-americano, que se dá através do Poder Judiciário, em todas as suas instâncias, funcionando a Suprema Corte como tribunal constitucional, restringindo-se ao controle concreto de constitucionalidade ${ }^{40}$. Nos sistemas especiais, também chamados de controle político (sistema defendido por Kelsen, adotado na Áustria, Alemanha, Espanha, Portugal, Itália e outros), o controle se dá através de órgão constitucional Tribunal ou Corte Constitucional - e pode restringir-se à apreciação prévia de atos normativos e leis (caso da França). Já o sistema de controle misto ou híbrido, adotado no Brasil, inclui tanto o controle jurisdicional concreto ou difuso em todas as instâncias do Poder Judiciário, com decisão, em última instância, do Supremo Tribunal Federal, por meio de recurso extraordinário (CF, art. 102, III), como o controle abstrato ou concentrado (igualmente jurisdicional), através de ações diretas ao STF (CF, art. 103).

No Brasil, a convivência entre os dois sistemas clássicos de fiscalização de constitucionalidade tem sido bastante problemática, forçando o STF, os legisladores e juristas a construirem soluções que tendem a harmonizá-los. Nem sempre, contudo, as respostas do STF, ou mesmo do legislador, têm sido coerentes e sistemáticas. Necessário e útil, então, avaliar esses resultados.

\section{PECULIARIDADES DO SISTEMA BRASILEIRO DE CONTROLE DE CONSTITUCIONALIDADE}

O sistema nacional de verificação de constitucionalidade é tido como misto ou híbrido, em face da adoção de técnicas muito diversas (e até opostas) de controle de constitucionalidade. A compreensão das vicissitudes, méritos e vícios de tal sistema (fruto das opções históricas dos legisladores, políticos e administradores), passa pela explicitação, ainda que sintética, da natureza e fundamento dos instrumentos de controle (2.1) e pela avaliação crítica dos meios encontrados para a solução de problemas práticos (2.2).

\subsection{As diversas técnicas de fiscalização de constitucionalidade}

\subsubsection{Controle Jurisdicional da Administração (verificação indireta de constitucionalidade)}

A Lei $n^{\circ} 221$, de 20.11.189441, ao definir os limites entre a legalidade e o mérito dos atos administrativos 
a propósito do âmbito da ação sumária especial (ação destinada a invalidar atos ou decisões da administração federal, lesivos aos interesses individuais), foi a primeira tentativa clara e inequívoca de garantir o cidadão contra o Estado, abrindo caminho para a adoção explícita do sistema único de controle da Administração, feita pela Constituição de $1946^{42}$, e constituindo, no plano material, a primeira forma de controle de constitucionalidade indireta. A introdução, no sistema jurídico brasileiro, do instituto da ação popular (texto da Constituição de 1946 e sua regulamentação, Lei 4.717/65), o alargamento de seu âmbito de aplicação, aliado ao amplo repertório de meios processuais previstos na Constituição de 1988, outorgaram ao cidadão brasileiro um elenco de instrumentos de controle do Estado, que não encontra similar em outros sistemas jurídicos ${ }^{43}$.

Sendo assim, pela via jurisdicional, o indivíduo pode controlar os atos administrativos preventivamente, quando procura sustar ato lesivo, em via de execução, e a posteriori, quando intenta ação para ressarcir prejuízo decorrente de execução administrativa. Tais procedimentos, no Brasil, são propostos perante a Jurisdição Criminal, direta ou indiretamente (o controle direto, no âmbito criminal, tem cabimento quando em jogo a liberdade de locomoção do indivíduo, ameaçado ou preso, por via do recurso de habeas corpus; o indireto, quando o administrado, alegando violação criminosa de direito por funcionário, denuncia-o, a fim de que lhe seja imposta uma sanção penal, por abuso de autoridade, por exemplo, nos termos da Lei $\mathrm{n}^{\mathrm{o}} 4.898 / 65$, na qual o Poder Judiciário examina a pretensa ilegalidade do ato administrativo como um meio de julgar a responsabilidade do funcionário) e, perante a Jurisdição Civil, quer através dos remédios processuais comuns, quer através de remédios especiais ou extraordinários ${ }^{44}$.

No Brasil, então, configurada uma situação contenciosa entre o administrado e a Administração, empregam-se as ações comuns, sempre que não exista ação especial prevista em lei processual: é o caso dos interditos possessórios, quando o esbulho ou turbação for consequência de ato ou fato administrativo. Os meios processuais específicos, em número limitado, destinam-se única e exclusivamente à composição de situações contenciosas entre a Administração e os administrados e podem ser propostos pela Administração ou contra ela. São eles: o mandado de segurança (individual e coletivo), a ação popular, a ação civil pública, o processo judicial de desapropriação, a ação executiva fiscal, a ação de nulidade de patente de invenção e de marca de indústria e o habeas data.
Dessa sistemática advém um amplo controle jurisdicional da Administração, extensível mesmo ao mérito dos atos administrativos, já que a Constituição põe como limites à atuação da Administração Pública a obediência aos princípios da legalidade, impessoalidade, moralidade e publicidade (CF, art. 37, caput). Além disso, ao administrado está garantido o contraditório e a ampla defesa $\left(\mathrm{CF}\right.$, art. $\left.5^{\circ}, \mathrm{LV}\right)$ bem como a motivação das decisões administrativas dos tribunais (CF, art. 93, X), de modo que resta inequívoca a possibilidade de se anularem atos administrativos discricionários, desde que a Administração não ultrapasse "os limites da discricionariedade; neste caso, por o Judiciário invalidar o ato porque a autoridade ultrapassou o espaço livre deixado pela lei e invadiu o campo da legalidade" 45 .

A tendência de reforçar-se o controle jurisdicional sobre a Administração, ficou claramente delineada na Constituição Federal de 1988, inaugurando um caminho fecundo que Almiro do Couto e Silva denominou "democratização da defesa do interesse público" porque permite aos cidadãos agirem pro populo, isto é, postularem em juízo, "a invalidação de atos lesivos ao interesse público, com a responsabilização de seus autores" $"$. Com o amplo repertório de meios de controle do Poder Público instituídos na Constituição e na legislação infraconstitucional - ações diretas de inconstitucionalidade por ação ou omissão, Lei da Ação Civil Pública e todas as outras formas de controle especificamente administrativo, "a lesão ao interesse, individual, difuso ou coletivo, dá legitimação para provocar a manifestação do Poder Judiciário, num amplo leque de matérias de utilidade pública ${ }^{47}$, de forma que, além de direitos subjetivos - direitos constitucionalmente garantidos - também restam protegidos os interesses legítimos. Assim, no Brasil, chegou-se a uma concepção de pleito civil, lato sensu, "em que se tratam pretensões de direito público, como se tratam pretensões de direito privado, só se reconhecendo a hierarquia das regras jurídicas [...], mas estabelecida a justiça igual sob lei processual igual"48, salvo exceções como a Lei das Execuções Fiscais (Lei 6.839/80) e, mais modernamente, a Lei de Processo Administrativo.

\subsubsection{Controle difuso (e concreto)}

A Jurisdição Constitucional propriamente, com a adoção da técnica de controle difuso de constitucionalidade, surgiu com a primeira Constituição republicana, uma vez que a Constituição Imperial, de 1824 só previa controle da Administração feito pelo Conselho de Estado, nos moldes do contencioso administrativo francês. A Constituição de 1891, prati- 
camente baseada na Constituição dos EUA de 1787, instituiu, pela primeira vez, o sistema de tripartição dos Poderes, "harmônicos e independentes entre si". O Poder Legislativo foi entregue ao Congresso Nacional, dividido em duas Casas, a dos representantes do povo, a Câmara dos Deputados, e a Casa dos Representantes dos Estados-membros, o Senado (art. 16). O Poder Executivo passou a ser exercido pelo "Presidente da República dos Estados Unidos do Brasil como chefe eletivo da Nação" (art. 41). E, no âmbito do Poder Judiciário, criou-se, à semelhança da Suprema Corte norte-americana como órgão de cúpula, o Supremo Tribunal Federal (art. 55 c/c arts. 56 e 59). Com a reforma constitucional de 1926, houve a previsão expressa para o controle difuso de constitucionalidade, feito, principalmente, através de recurso extraordinário.

Atualmente, previsto no art. 102, III, da Constituição da República e no art. 541 do Código de Processo Civil (com a redação dada pelas Lei $\mathrm{n}^{\circ}$ 8.950/94 e $\left.\mathrm{n}^{\mathrm{o}} 11.418 / 06\right)$, o recurso extraordinário pode ser proposto ao STF, sempre que as decisões dos tribunais inferiores (em única ou última instância), contrariarem dispositivo da Constituição (alínea "a"), declararem a inconstitucionalidade de tratado ou lei federal (alínea "b") ou julgarem válida lei ou ato de governo local em face da Constituição (alínea "c"). Os requisitos de admissibilidade são os contidos na lei processual civil. Isto significa dizer que, no tocante ao processamento do recurso extraordinário, valem as regras postas no Código de Processo Civil, isto é, constitui-se um pleito civil na terminologia adotada por Pontes de Miranda.

$\mathrm{O}$ recurso extraordinário pode ser proposto em qualquer processo, independentemente de seu objeto ou causa de pedir e, por isso, constitui instrumento do controle difuso de constitucionalidade, sistema em que a guarda Constituição é confiada a todo Poder Judiciário (órgãos dispersos). O juiz, em um caso, deixa de aplicar a lei por esta violar a Constituição. Tal controle é também repressivo (reage contra ato irregular existente); concreto, porque ocorre por ocasião da aplicação de atos normativos a casos concretos (lides ou providências administrativas); subjetivo, pois se prende ao interesse processual de um sujeito; incidental, na medida em que a finalidade do processo é outra que não a verificação de constitucionalidade e por via de exceção, uma vez que a discussão de constitucionalidade é enxertada em um processo em curso. A discussão de constitucionalidade não suspende o curso do processo, e, por isso, para chegar ao STF, é preciso esgotar todas as instâncias. Na prática, se a decisão do tribunal inferior ou do juiz não for objeto de recurso extraordinário (por qualquer razão), fará coisa julgada e produzirá efeito entre as partes.
Este sistema comporta, imediatamente, dois questionamentos: o primeiro deles diz respeito ao princípio democrático, pois, como os juízes têm a possibilidade de anular uma lei aprovada pelos representantes da maioria do povo? Já a segunda pergunta que pode ser feita diz respeito aos valores constitucionais, entendidos como consensos: qual é o direito que uma geração tem de decidir sobre o destino de outras gerações? Ou: há consenso em torno de questões polêmicas? Se há um consenso na sociedade, por que os juízes dissentem? Alguns não captaram o consenso ${ }^{49}$ ? Outros argumentos podem ser articulados contra o sistema de fiscalização difusa, tais como a possibilidade de desarmonia de decisões e a "diluição do poder de controlo pelas centenas de tribunais existentes, com o consequente risco de não acatamento das decisões pelos órgãos políticos, legislativos e administrativos" ${ }^{50}$.

$\mathrm{Na}$ raiz do controle difuso, temos a garantia dos direitos individuais (dimensão doutrinária do liberalismo) $)^{51}$ e o princípio do rule of law (dimensão institucional), porque Estado de Direito é aquele em que existam mecanismos constitucionais que impedem ou obstaculizam o exercício arbitrário, ilegítimo e ilegal do poder. Entre outros, faz parte desse mecanismo, "o eventual controle do Parlamento no exercício do poder legislativo ordinário por parte de uma corte jurisdicional a quem se pede a averiguação da constitucionalidade das leis" "52). Para atenuar essa contradição, a Constituição Magna da República Brasileira impõe que o Senado, no exercício de sua competência, através de Resolução, suspenda "a execução, no todo ou em parte, de lei declarada inconstitucional por decisão definitiva do Supremo Tribunal Federal" (art. 52, X).

Forçoso é reconhecer-se, todavia, os argumentos favoráveis a este modo de fiscalizar a constitucionalidade dos atos normativos. O primeiro deles diz respeito à dignidade dos tribunais enquanto órgãos de soberania ("há juizes em Berlim"), raiz do princípio do Estado de Direito; o segundo, que o sistema obriga e responsabiliza os juízes no cumprimento da Constituição e, finalmente, por meio desse sistema, as questões de constitucionalidades são postas como questões jurídicas e não políticas, o que permite a maior eficácia possível da Constituição ${ }^{53}$.

No que diz respeito aos efeitos da arguição de inconstitucionalidade pela via difusa e incidental, é pacífico na doutrina e na jurisprudência da Suprema Corte, que são inter partes e ex tunc. Neste sentido, frise-se que a inconstitucionalidade opera efeito $e x$ tunc em relação a todo o dispositivo ou lei declarada inconstitucional, inclusive o efeito revogatório; segue daí que, havendo lei anterior compatível com a Constituição, esta há de ser aplicada, sem qualquer 
solução de continuidade; não se trata de repristinação, mas, tão-somente, de eficácia plena de lei que, pela inconstitucionalidade de lei posterior, nunca fora validamente revogada ${ }^{54}$. A propósito da inexistência de efeito revogatório ou derrogatório de leis ou dispositivos de leis declarados inconstitucionais, importa mencionar a doutrina de Clèmerson Merlin Clève $^{55}$, o qual, repercutindo a pacífica orientação do Supremo Tribunal Federal, assevera:

Por que o ato inconstitucional, no Brasil, é nulo (e não, simplesmente, anulável), a decisão judicial que assim o declara produz efeitos repristinatórios. É que, sendo nulo, do ato inconstitucional não decorre eficácia derrogatória das leis anteriores. A decisão judicial que decreta (rectius, que declara) a inconstitucionalidade atinge todos 'os possíveis efeitos que uma lei constitucional é capaz de gerar', inclusive a cláusula expressa ou implícita de revogação. Sendo nula a lei declarada inconstitucional, diz o Ministro Moreira Alves, 'permanece vigente a legislação anterior a ela e que teria sido revogada não houvesse a nulidade'.

Ainda no que concerne à extensão do controle difuso de constitucionalidade, que opera efeitos ex tunc e inter partes, várias situações difíceis podem surgir. Tome-se como exemplo o caso das leis tributárias do Município de Porto Alegre (Leis Complementares Municipais $n^{\text {os }} 312 / 93$ e 333/940), que instituíram a chamada progressividade extrafiscal do IPTU, ou tributação progressiva no tempo, com vistas ao cumprimento da função social da propriedade antes da promulgação da Lei Federal $n^{0} 10.257$, de 10 de julho de 2001 (Estatuto da Cidade). Tais leis foram sistematicamente impugnadas pelos contribuintes por via de controle difuso de constitucionalidade e, chegando os processos ao STF, restou pacificado o entendimento de que eram inconstitucionais as leis municipais que tivessem estabelecido, antes da Emenda Constitucional $n^{\circ} 29 / 2000$, alíquotas progressivas para o IPTU, salvo se destinada a assegurar o cumprimento da função social da propriedade urbana" (Súmula 668). Antes mesmo da edição da súmula referida, o STF já vinha firmando posição no sentido de que "a única progressividade admitida, pelo texto constitucional, é aquela de índole extrafiscal, que só pode ser instituída pelo Município com a finalidade exclusiva de fazer cumprir a função social da propriedade".

$\mathrm{Na}$ medida em que tais decisões não geram efeitos erga omnes (porque não proferidas em sede de controle concentrado), torna-se uma questão tormentosa para a Administração Municipal reconhecer, de plano, a inconstitucionalidade de leis municipais válidas e deixar de aplicá-las, em face de sua vinculação à Legalidade formal. À primeira vista, estaria proibida de fazê-lo, considerando o sistema de repartição de competências funcionais postos na Constituição da República. A solução encontrada pela ProcuradoriaGeral do Município, exarada no Parecer no 1109/2004 ${ }^{56}$ foi verificar se o Executivo Municipal poderia, no controle de constitucionalidade, sob o argumento da inconstitucionalidade, negar-se a dar cumprimento a uma dada decisão legislativa (lei ou ato normativo). Essa verificação só podia ser feita mediante um exame dos limites da atividade interpretativa quando se trata de concretizar a Constituição. Os relatores do Parecer iniciaram a argumentação trazendo a exposição do Ministro Moreira Alves, no relatório de ação direta de inconstitucionalidade, segundo a qual, "os Poderes Executivo e Legislativo, por sua Chefia, podem determinar aos seus órgãos subordinados que deixem de aplicar administrativamente as leis ou atos com força de lei que considerem inconstitucionais " (ADIn nº 221, Rel. Min. Moreira Alves, DJ de 22.10.1992).

Após fazerem digressões sobre o papel da Administração na interpretação e concreção da Constituição, o Princípio da Legalidade e o Preceito da Proporcionalidade, os relatores concluíram que havia que se reconhecer a nulidade dos lançamentos perpetrados sob a égide das leis municipais no 312/93 e 333/94, porque a finalidade de adequar a ação da Administração à Constituição é um dever inafastável, na medida em que o STF já declarara que as leis municipais editadas antes do Estatuto da Cidade eram inconstitucionais. Além disso, ponderaram que tal anulação (o meio adotado) era adequada para prevenir situações futuras e para recompor o status quo ante, além de ser indispensável para assegurar a fiel concreção dos comandos constitucionais e infraconstitucionais sobre a matéria e, finalmente, em uma ponderação de meios e fins, verificava-se que a não concessão de Certidão Negativa de Débito aos contribuintes que possuíssem dívidas constituídas com base nas leis consideradas inconstitucionais pela Administração Fazendária, era medida excessiva, uma vez que o IPTU progressivo no tempo, para assegurar a função social da propriedade urbana, só pode ser validamente exigido dos munícipes a partir de 2001. Finalmente, asseveraram que, se na maioria dos casos, sequer tinha havido o pagamento da dívida constituída, não restava caracterizado qualquer prejuízo para a Administração a anulação de tais lançamentos. Para ilustrar, transcreve-se a conclusão do referido parecer:

Ante o exposto, se pode concluir que, ausente à época da publicação das leis municipais $n^{\circ}$ 312/93 
e 333/94, a lei federal exigida pelo artigo $182, \S 4^{\circ}$, II, da $\mathrm{CF} / 88$, não poderia o legislador municipal e, menos ainda, o Chefe do Poder Executivo, dar executoriedade e dispor, no âmbito municipal, sobre a progressividade extrafiscal da forma que hoje é disciplinada pela Lei Federal n ${ }^{\circ}$ 10.257/2001. Como até o momento, as leis municipais em comento não foram declaradas inconstitucionais em sede de Ação Direta de Inconstitucionalidade, resta ao Executivo deliberar, não sobre a sua validade - eis que válidas são, pela sistemática constitucional em vigor -, mas sim sobre a sua eficácia, uma vez que ao Chefe do Poder Executivo cabe, se entender inconstitucional determinado regramento edilício, deixar de aplicá-lo administrativamente. Pode, portanto, o Executivo, no plano municipal, deixar de cumprir os ditames das leis municipais no $312 / 93$ e 333/94, ao argumento de sua inconstitucionalidade, mesmo que ainda não declarada pelo Poder Judiciário Estadual, na forma prevista no art. 95, XII, d, da Carta da Província. Não seria razoável que o Executivo se visse compelido a aplicar lei que considerasse, fundamentadamente, incompatível com a ordem constitucional vigente, se não dispusesse de outra possibilidade de provocar um pronunciamento jurisdicional sobre a matéria.

Considerando ter o Brasil importado o sistema de controle difuso sem dar relevância aos precedentes (regra do stare decisis) ${ }^{57}$ e o STF, à semelhança da Suprema Corte Federal dos EUA, ser órgão supremo do Poder Judiciário e não Tribunal Constitucional stricto sensu ${ }^{58}$, foi feita a reforma constitucional de 2004, prevendo efeito vinculante aos julgamentos e uniformização dos procedimentos, ao introduzir-se um novo requisito de admissibilidade para os Recursos Extraordinários. A ratio da norma estatuída no art. $102, \S 3^{\circ}$ da CF e no art. 543-A da Lei 11.418/06 (que regulamenta o dispositivo constitucional) é a uniformização mínima dos procedimentos e a plena efetividade das novas disposições constitucionais, garantindo-se a necessária segurança dos jurisdicionados ${ }^{59}$. Com isso, pretendeuse diminuir o número e, ao mesmo tempo, acelerar a marcha dos recursos nos tribunais superiores. A finalidade é fortalecer a posição do STF como guardião da Constituição, para que este, deixando de operar como terceira instância, possa decidir apenas as questões constitucionais relevantes.

Sendo assim, a introdução de novo requisito objetivo de admissibilidade do recurso extraordinário - a demonstração da repercussão geral (mecanismo de filtragem que, segundo Tucci ${ }^{60}$, é "muito assemelhado ao antigo sistema da relevância") - permite que apenas alcancem o STF as teses relevantes para a Nação, fazendo com que a Suprema Corte "seja reconduzida à sua verdadeira função, que é a de zelar pelo direito objetivo - sua eficácia, sua inteireza e a uniformidade de sua interpretação"61. Nos termos da lei que regulamenta o $\S 3^{\circ}$ do art. 102, a existência de repercussão geral é pressuposta, de modo expresso, nas hipóteses em que o recurso extraordinário contrariar súmula ou jurisprudência dominante do STF. Tal presunção legal decorre do fato de que a existência de súmula ou precedente judicial consolidado já indica que a matéria se reveste de amplo interesse.

Adotada a nova sistemática de processamento dos recursos extraordinários, até 17/02/2010, o STF conta com trinta e nove matérias com mérito da repercussão geral julgados e dezessete reafirmaçoes da jurisprudência dominante. Dentre essas matérias, figuram questões de repartição de competência entre jurisdições, relativas à tributação, processo penal, prescrição e decadência em matéria tributária, direitos trabalhistas, regime de servidores públicos, entre outras $^{62}$.

A sistemática da repercussão geral se insere num processo mais geral de aproximação do sistema difuso de controle de constitucionalidade ao sistema de controle concentrado, iniciado no STF, e que leva em conta a eficácia erga omnes do controle abstrato. A respeito da elaboração constante do Supremo Tribunal em matéria de controle de constitucionalidade, o Ministro Sepúlveda Pertence, na Ação Declaratória de Constitucionalidade $n^{\circ}$ 4-6 DF , assim se manifestou:

\begin{abstract}
Vivemos um sistema singular em que, ao cabo de um longo processo de acomodação, de acoplagem, terminamos com a convivência integral dos dois sistemas clássicos de controle de constitucionalidade. [...] O Brasil, no entanto, importou, com a República, o sistema difuso americano, enfraquecido, porém, entre nós, pela ausência do stare decisis, e foi, talvez por isso, pouco a pouco, fazendo concessões ao sistema austríaco até que, em 1965, de repente - à base com uma fundamentação despretensiosa ligada ao congestionamento do Supremo Tribunal Federal - se completou esse acoplamento e passaram a conviver os dois sistemas na sua integralidade. A partir daí, é claro, cabe a este Tribunal construir um sistema de convivência, de harmonização desses dois sistemas, no qual é fatal, dada a eficácia universal do controle abstrato, que este venha a predominar sobre o controle difuso.
\end{abstract}

A reforma constitucional, contudo, não resolveu todas as aporias do sistema difuso e concreto de verificação de constitucionalidade, principalmente porque o STF, na sua constante reelaboração da 
Constituição, insiste em misturar as técnicas de controle, de modo que, no particular, o legislador pensou "fazer um beija-flor", e o Supremo acabou "fazendo um morcego". Cabe, então, discorrer sobre o sistema de controle concentrado e abstrato de constitucionalidade vigente no País.

\subsubsection{Controle concentrado (e abstrato)}

A partir da adoção da representação interventiva (positivada efetivamente na Constituição de 1934) iniciou-se, em meio a dificuldades teóricas e práticas, o controle abstrato e concentrado de normas no País. Com a reforma constitucional de 1965, foi introduzido, ao lado da representação interventiva, o processo de controle abstrato, confiado, nos moldes da intervenção, ao Procurador-Geral da República ${ }^{63}$.

Retornando o País à ordem democrática, a Constituição de 1988 veio a consagrar um amplo regime de proteção (garantia) dos direitos fundamentais, um severo controle jurisdicional da Administração e um sistema "misto" de verificação de constitucionalidade, uma vez que todos os órgãos do Poder Judiciário podem declarar a inconstitucionalidade de ato normativo e, paralelamente, o STF, como guardião da Constituição, conhece, originariamente, ações diretas, na maioria dos casos de natureza declaratória, fazendo controle concentrado ou abstrato de constitucionalidade. Os requisitos e processamento de tais ações estão previstos no art. 103 e parágrafo, da Constituição da República e nas Leis 9.868/99, 9.882/99 e, mais recentemente, Lei 12.063/09, que, além de disciplinar a Ação Direta de Inconstitucionalidade por Omissão (ADO), modifica, em parte, a Ação Direta de Inconstitucionalidade (ADIn) e a Ação Declaratória de Constitucionalidade (ADC), com inclusão, na Lei 9.868/99, do Capítulo II A. Consoante Gilmar Ferreira Mendes ${ }^{64}$, "ao ampliar, de forma marcante, a legitimação para propositura da ação direta de inconstitucionalidade (art. 103), permitindo [...] que as controvérsias relevantes sejam submetidas ao STF mediante processo abstrato de normas", a Constituição acabou por reduzir o significado e função do controle de constitucionalidade difuso e concreto.

Principal instrumento de controle concentrado de constitucionalidade é a ação direta de inconstitucionalidade, de cunho declaratório porque visa criar uma certeza jurídica e cuja legitimação ativa é dada àquelas pessoas que representam interesses coletivos. A Lei 9.868/99 regula o processo da ação e os efeitos das decisões. Tais efeitos são, via de regra, vinculativos, (rectius, vinculantes) e produzem eficácia erga omnes e ex tunc. No entanto, a Lei 9.868/99 trouxe a inovação denominada "atenuação dos efeitos do reconhecimento da inconstitucionalidade," de modo que o Tribunal, ao julgar a ação, declara a partir de qual momento a decisão produzirá efeito. Esta possibilidade é dada em função de que as decisões em ações diretas, ao produzirem eficácia erga omnes e ex tunc, podem atingir irremediavelmente situações jurídicas constituídas sob a égide da lei declarada inconstitucional. Assim, em nome da segurança jurídica e da proteção à confiança, e em face de relevante interesse social, poderá ser restringido o reconhecimento da inconstitucionalidade ou fixado o momento da produção de efeitos da decisão, mediante $2 / 3$ dos votos do Plenário. Importa destacar, neste particular, que tal atenuação faz com que, tecnicamente, a nulidade das normas declaradas inconstitucionais seja transformada em anulabilidade.

A Emenda Constitucional $n^{0} 3 / 93$ introduziu no sistema brasileiro de controle concentrado de constitucionalidade, a Ação Declaratória de Constitucionalidade e a Arguição de Descumprimento de Preceito Fundamental $(A D P F)$. O procedimento de tais ações está disciplinado na Lei 9.868/99. Quanto à primeira, constitui uma espécie de controle preventivo, porque alguém (os legitimados) se adianta à discussão que pode ocorrer (ou está ocorrendo) na via incidental e difusa. Há, então, a necessidade de uma legitimação para agir in concreto (não formal), relacionada com a existência de um estado de incerteza gerado por controvérsias acerca da legitimidade de determinada lei federal. O quid, aqui, é que exista uma controvérsia ou dúvida quanto à legitimidade de uma norma. Os legitimados para agir são os mesmos da $A D I$, e as decisões de mérito, na mesma medida, produzem eficácia erga omnes e efeitos vinculativos.

$\mathrm{Na} A D C \mathrm{n}^{\mathrm{o}}$ 5-2, do Distrito Federal, ajuizada por provocação do Procurador-Geral da República, por exemplo, além de afirmar a situação de incerteza quanto à constitucionalidade de dispositivos da Lei 9.534/97 (dispõe sobre registros públicos), o autor trouxe ao conhecimento do STF, no pedido inicial, a controvérsia consubstanciada em seis processos, originários de vários Estados diferentes da Federação: a Ação Cautelar 9811179-4, de Campo Grande (MS), cuja decisão concedeu liminar para desobrigar os autores ao cumprimento da lei; o Mandado de Segurança Coletivo no 98000462-4, do Rio Grande do Norte, deferindo liminar suspensiva dos efeitos de Provimento editado pelo Corregedor de Justiça daquele Estado, que mandava cumprir a lei; o Mandado de Segurança $n^{\circ}$ 98000388, de Rondônia, cuja liminar deferida permitiu aos notários continuar cobrando os serviços de registro de pessoas naturais; o Mandado de Segurança 98002001433, do Distrito Federal, no qual os impetrantes pediram administrativamente para 
continuarem cobrando das pessoas que não fossem reconhecidamente pobres, deferido em sede de Agravo Regimental; a Ação Declaratória Constitutiva Negativa de Relação Jurídica Tributária de São Paulo (Processo 369/98), em que foi deferida antecipação de tutela para contemplar o pedido do autor, e, finalmente, o Processo 598097764, da $1^{\text {a }}$ Vara da Fazenda Pública de Porto Alegre, cuja liminar, antecipatória de tutela, determinou a não aplicação da lei em todo o Estado do Rio Grande do Sul. O Presidente do TJRS suspendeu a antecipação de tutela e, em Agravo Regimental, tal decisão restou mantida pelo Pleno. Como se vê, a controvérsia há que ser judicial e não doutrinária. Ademais disso, a prevalecer a orientação do STF, consubstanciada na $\mathrm{ADC} / \mathrm{MC} \mathrm{n}^{\circ}$ 8, contida no voto do Relator, Ministro Celso de Mello, há que se demonstrar, "em termos numericamente relevantes, ampla controvérsia judicial em torno da validade de jurídica da norma federal" ${ }^{65}$.

No que tange à Arguição de Descumprimento de Preceito Fundamental ( $A D P F)$, para as finalidades deste estudo, importa apenas ressaltar que, inicialmente, a previsão constitucional era tão somente de propositura do chamado "incidente de inconstitucionalidade", instrumento que permitia a apreciação direta do STF, de controvérsia sobre a constitucionalidade de lei ou ato normativo federal, estadual ou municipal, inclusive atos normativos anteriores à Constituição (art. 102, $\S 1^{\circ}$, da CF).

Na sistemática anterior à Lei 9.882/99, tal incidente só poderia ser provocado pelo Procurador-Geral da República, pelo Advogado-Geral da União, pelo Procurador-Geral de Justiça ou Procurador-Geral de Estado, desde que houvesse perigo de lesão à segurança jurídica, à ordem ou às finanças públicas. Acolhendo o incidente, o STF poderia determinar a suspensão do processo em curso, para proferir decisão exclusivamente sobre a questão constitucional suscitada. Regulamentada definitivamente pela Lei 9.882/99, em meio a grandes controvérsias judiciais e doutrinárias $\left(A D I n \mathrm{n}^{\circ} 2.231\right.$, proposta pela $\left.\mathrm{OAB}\right), \mathrm{o}$ certo é que o instituto vingou. Ação por meio da qual a decisão sobre a inconstitucionalidade ou não de atos federais, estaduais ou municipais impugnados perante os tribunais ordinários pode ser avocada pelo STF, a $A D P F$ tem como parâmetro de controle "os preceitos fundamentais identificados ou identificáveis na Constituição"66. Quais são os preceitos fundamentais que, violados, ensejam a propositura da ação, ainda está em aberto.

No que respeita à natureza da $A D P F$, chama a atenção a posição do Ministro Carlos Ayres Britto, relator da $A D P F \mathrm{n}^{\circ}$ 83-1, do Espírito Santo, verbis:

\begin{abstract}
Começo por confirmar o que tenho dito a respeito da natureza jurídica da ADPF. Ela ostenta uma multifuncionalidade processual - espécie de soldado de reserva - que me parece de duvidosa constitucionalidade. Entretanto, [...] tenho-me rendido ao princípio constitucional de presunção de validade dos atos legislativos, de modo a momentaneamente acatar o instituto da ADPF tal como positivamente gizado. Logo, a ADPF como ferramenta processual apta a ensejar tanto a abertura do processo de controle concentrado de constitucionalidade quanto a instauração de processo de controle desconcentrado (comumente designado por "difuso" e em caráter "incidental", ambos de índole jurisdicional. Alcançando, no mesmo tom, assim os atos do Poder Público editados anteriormente à Constituição como os de edição a ela posterior.
\end{abstract}

Gilmar Ferreira Mendes assevera que a $A D P F$ alterou profundamente o sistema de controle dos atos normativos no Brasil porque, em primeiro lugar, "permite a antecipação de decisões sobre controvérsias constitucionais relevantes", ao evitar que as mesmas tenham um desfecho definitivo "ao arrepio da 'interpretação autêntica' do STF" ${ }^{67}$; segundo, a $A D P F$ serve para resolver controvérsia relevante sobre a legitimidade de direito ordinário pré-constitucional, o que só poderia ser feito mediante o manejo do recurso extraordinário. Esse é o caso da $A D P F 130$, do Distrito Federal, julgada em 30/04/2009, que discute a legitimidade da Lei de Imprensa de 1967. Neste particular, a decisão foi no sentido de que não era possível recepcionar, em bloco, a referida lei. $\mathrm{Na}$ ementa do acórdão, o STF afirma ser a $A D P F$ "fórmula subsidiária de controle de concentrado de constitucionalidade" e "via adequada à impugnação de norma pré-constitucional"68. Por último, e não menos importante, é a circunstância de a $A D P F$, além de fornecer uma diretriz segura para o juízo de legitimidade de atos de teor idêntico editados pelos órgãos municipais, oferecer "respostas adequadas para dois problemas básicos do controle de constitucionalidade no Brasil: o controle da omissão inconstitucional e a ação declaratória nos planos estadual e municipal" 69 .

A verificação da inconstitucionalidade por omissão era feita, até o advento da Lei 12.063/09, ou por meio da ADPF, ou do Mandado de Injunção, ação mandamental, com procedimento análogo ao Mandado de Segurança, por força de decisão do STF no MI 107/DF RTJ 133/11. A inconstitucionalidade por omissão pode decorrer de omissão políticoadministrativa, de medida judicial ou de lei, sendo esta última a hipótese mais relevante, uma vez que 
é a falta de norma regulamentadora que torna inviável o exercício de direitos e liberdades constitucionais ou das prerrogativas inerentes à nacionalidade, à soberania e à cidadania (caso do Mandado de Injunção), ou torna sem efetividade uma norma constitucional (hipótese da ação de inconstitucionalidade por omissão).

Os institutos, no entanto, não se confundem: a $A D O$, de natureza declaratória, não tem por objetivo a defesa de um direito subjetivo, de um interesse juridicamente protegido ou lesado. O seu objeto é a defesa da Constituição e da integridade da ordem jurídica, uma vez que a pretensão aduzida é a de que reste declarada a mora do legislador frente a uma omissão legislativa e sejam adotadas medidas para o suprimento da omissão a ser feita pelo próprio órgão omisso. Já o Mandado de Injunção visa a obter o direito em favor do impetrante, quando inexistem normas regulamentadoras do artigo constitucional que outorgue direitos, liberdades ou prerrogativas. $\mathrm{O}$ mandado de injunção não é instrumento destinado a obter a produção de normas regulamentadoras.

No que concerne à $A D O$, deve seguir quase que integralmente, o procedimento da $A D I n$, com alterações sensíveis como a regra que atribui ao Relator o poder de solicitar, ou não, a manifestação do AdvogadoGeral da União (obrigatória na $A D I n$ ) e a que admite a interposição de Medida Cautelar (o que não era admitido na jurisprudência do STF ). Ressalte-se ainda, que a adoção de procedimento semelhante ao da $A D I n$ abre espaço para o reconhecimento da fungibilidade processual, modo que a hipótese de omissão parcial já torna possível a eventual conversão da $A D I$ em $A D O$, como forma de superação de eventual inépcia da petição inicial. O mais importante é que o STF, ao conhecer uma $A D O$, poderá suspender processos judiciais ou procedimentos administrativos em que se discuta a aplicação de lei ou ato normativo (omissão parcial) e, que, ao lhe dar provimento, poderá indicar ao legislador "prazo razoável", para suprir a omissão, e à Administração, necessariamente o prazo de trinta dias (a lei repete, praticamente, a fórmula do art. 103, parágrafo $2^{\circ}$, da $\mathrm{CF}$ ).

Justifica-se o controle concentrado ou abstrato, principalmente em razão da segurança jurídica (certeza do direito), em face da eficácia geral das decisões sobre inconstitucionalidade. É o meio adequado para o aprofundamento das questões constitucionais e para a formação da jurisprudência, que acaba por enriquecer o conteúdo da Constituição ${ }^{70}$. Através dela, as grandes questões nacionais podem ser discutidas, porque as ações propostas, via de regra, integram a discussão pública, como o caso do uso de células tronco, legitimidade da lei de imprensa, exação das atividades notariais, ações afirmativas, etc.

Contudo, não faltam argumentos críticos ao controle concentrado: há o perigo de conceder-se ao STF um poder exagerado, ou, ao contrário, o órgão fica sujeito a todo tipo de pressão vinda de outros poderes ou mesmo da opinião pública. Ademais, corre-se o risco de uma cristalização jurisprudencial desproporcional e errônea, como é o caso da exigência de preliminar formal em recursos extraordinários interpostos contra ADIns que discutem a constitucionalidade de leis estaduais e municipais.

Prescindindo de analisar os demais meios de controle concentrado de constitucionalidade, tais como a reclamação e a representação interventiva, cabe, finalmente, discutir a hipótese mais problemática no sistema de verificação de constitucionalidade no Brasil, que é a possibilidade de recurso extraordinário em sede de controle abstrato de leis municipais e estaduais.

\subsection{Hipótese problemática: recurso extraordinário no controle abstrato de leis municipais e estaduais}

Almiro do Couto e Silva, apreciando o controle abstrato e concentrado de leis estaduais e municipais, alertou para o fato de que a decisão da Reclamação 337-0 do Distrito Federal, ao admitir recurso extraordinário contra decisão de Tribunal regional que julga $A D I n$ de lei municipal ou estadual em face da Constituição, "atribuiu nova dimensão ao controle concentrado de constitucionalidade instaurado no plano estadual" e 'atropelou' "algumas noções básicas do processo, como a distinção entre recurso e ação" "71. Com razão. De fato, o STF, ao reconhecer que, sendo o controle concentrado de Lei Municipal hipótese excepcional (alegação de ofensa à norma constitucional estadual que reproduz dispositivo constitucional federal), o recurso extraordinário é necessário porque constitui o duplo grau de jurisdição nestas ações, "quis fazer um beijaflor e fez um morcego". Isso é assim porque, como assevera o professor gaúcho, o processo instaurado no plano estadual, em duas fases, acaba por transcender o controle do direito positivo estadual, invadindo a competência privativa do STF, de fazer o exame de constitucionalidade das leis estaduais. Além disso, dado que a Constituição não outorgou competência aos tribunais inferiores "para exercer controle abstrato de constitucionalidade de lei municipal [...] só em controle difuso, em face do caso concreto, é que será possível [...] declarar a inconstitucionalidade de lei municipal perante a Constituição Federal" ${ }^{\prime 72}$.

Assim sendo, admitir-se o recurso extraordinário na ação direta de lei estadual ou municipal frente à 
Constituição Estadual transforma o feito em ação direta frente à Constituição Federal, isto é, transforma a 'coisa' no que ela não é, em razão da diversa causa de pedir. Na ação proposta frente à Constituição Estadual, a pretensão é declaração de incompatibilidade de lei estadual ou municipal frente à Constituição Estadual; no pedido de ADin de lei estadual frente à Constituição Federal, o que se pretende é a declaração de inconformidade da lei estadual com a Constituição Federal. Ademais, "as decisões, nessas duas ações, igualmente são distintas: numa, o terminus comparationis que define o decisum é a Constituição Estadual, na outra a Constituição Federal"73.

Mas os problemas não terminam aí. Nas ADins em que o confronto é entre a lei municipal e a Constituição Estadual, a interposição do recurso extraordinário implica igualmente "mudança da causa de pedir e do pedido formulado naquela ação, transformando o recurso extraordinário em ADI de lei municipal perante a Constituição Federal", hipótese inexistente no nosso sistema constitucional. Isso se deve ao fato de "as decisões de Tribunal de Justiça em controle concentrado de constitucionalidade só indiretamente podem implicar lesão à Constituição Federal, porque há, em primeiro lugar e diretamente, lesão à Constituição Estadual." ${ }^{74}$ Nestes dois casos, ou há usurpação de competência do STF (da norma estadual) ou uma atribuição não outorgada a nenhum tribunal. Assim, o recurso extraordinário deixa de ser recurso e passa a ser $a c ̧ a \tilde{o}$, o que é uma incongruência e uma contradição. O confronto entre a lei municipal e a Constituição Estadual é mais problemático ainda, "pois importa criação, por via oblíqua ou indireta, de controle abstrato ou concentrado de constitucionalidade de lei municipal em face da Constituição Federal" 75 , hipótese inexistente e proscrita pela Constituição da República. Supondo um caso em que o Tribunal de Justiça julgue procedente tal ação e, por qualquer razão, não seja interposto o recurso extraordinário (que é facultativo), tal decisão, ao produzir efeitos erga omnes no âmbito estadual, teria a inevitável e nefasta consequência de vincular o próprio STF (este deixaria de exercer a sua missão constitucional). Conclui Almiro do Couto e Silva:

percebe-se que o controle de constitucionalidade de leis municipais frente a Constituição Estadual, com a possibilidade de interposição de recurso extraordinário, orienta-se em sentido contrário ao das razões que levaram o legislador constituinte a apenas permitir o controle de constitucionalidade incidenter tantum das leis municipais em contraste com a Constituição Federal.
Se tal sistemática não for modificada (porque o melhor seria não admitir recurso extraordinário nas hipóteses mencionadas), a dificuldade poderia ser contornada mediante a instituição de recurso extraordinário ex officio no controle concentrado de leis estaduais e municipais. O STF, todavia, não pensa assim, na medida em que tem laborado para tornar o morcego mais monstruoso, exigindo preliminar formal de repercussão geral nos recursos extraordinários interpostos de decisões de controle concentrado de normas estaduais e municipais. Neste particular, o STF sequer está atentando para as disposições contidas na Lei 11.418/06, no art. 543-A, $\S 3^{\circ}$ segundo as quais há repercussão geral sempre que o recurso impugnar decisão contrária a Súmula, ou jurisprudência dominante do Supremo Tribunal Federal. Nos mesmos termos, a disposição contida no $\S 1^{\circ}$ do art. 323 do RISTF: "Tal procedimento não terá lugar, quando o recurso versar questão cuja repercussão já houver sido reconhecida pelo Tribunal, ou quando impugnar decisão contrária a súmula ou a jurisprudência dominante, casos em que se presume a existência de repercussão geral'. Ora, aí reside uma contradição final, porque, a existência mesma do controle concentrado de constitucionalidade repousa na produção de segurança jurídica, ou, como afirmou o Ministro Nelson Jobim ${ }^{76}$ :

\begin{abstract}
na necessidade que tem o cidadão de saber e definir o 'seu trânsito social e econômico futuro, considerando o sistema legal vigente", é o Supremo Tribunal Federal, na condição de "guardião da Constituição", quem deve assegurar em todo o território a vigência plena das normas compatíveis com a Constituição, avocando a capacidade de assim fazê-lo em razão do princípio vital do Estado de Direito, o da segurança jurídica.
\end{abstract}

Por estas razões, quando o feito que julga a constitucionalidade de Lei Municipal frente à Constituição Estadual e Federal é uma ação direta, a preliminar formal de repercussão é dispensável, porque todos os argumentos expendidos no processo (do autor, dos demandados, do Tribunal), sem exceção, giram em torno de questões relevantes que transcendem os interesses subjetivos da causa. Não fosse assim, o Estado-membro, estaria apto a fiscalizar e tutelar in abstracto o direito objetivo positivado no texto constitucional federal e inviabilizar-se-ia, negando-se seguimento ao Recurso Extraordinário interposto em $A D I$, o controle em tese das normas municipais em face da Constituição.

Interpretar a lei processual no sentido de que, no âmbito do controle abstrato de constitucionalidade, 
é imprescindível a preliminar formal de repercussão geral é deveras simplificador. Significa não reconhecer que, se o Direito é algo que tem que ser construído diuturnamente, a norma efetivamente só ganha vida quando existe o labor de interpretação para aplicação. Antes disso, todas as leis ainda não são propriamente 'normas', mas textos escritos que podem não ter qualquer significação, isto é, não vivem.

\section{CONSIDERAÇÕES FINAIS}

A título de considerações finais, é possível afirmar que, se à Jurisdição, entendida como função estatal, cabe resolver, com força de coisa julgada, controvérsia surgida a propósito da aplicação do Direito, a ela é atribuída a competência de fiscalização de constitucionalidade e de legalidade dos atos de poder. De outra parte, se a Jurisdição Constitucional verifica a conformidade à Constituição (é relativa atos normativos gerais), à Jurisdição Administrativa, pedra basilar do Estado Democrático de Direito, cabe fazer o controle da legalidade da execução. No processo de controle da Administração, há a fiscalização indireta de constitucionalidade de atos individuais (atos administrativos em sua definição material). Os modos de organização de ambas variam no tempo e no espaço, dependendo, sempre, das opções do legislador histórico.

Conquanto existam vários modos de se organizar tanto a Jurisdição Constitucional quanto a Jurisdição Administrativa, foi adotado no Brasil o princípio da Jurisdição única, desde a primeira Constituição Republicana. Assim, o Judiciário, como um todo, conhece os litígios surgidos entre os cidadãos e o Estado, sejam eles controle da Administração, sejam de fiscalização da constitucionalidade das leis. Em um e em outro caso, os pleitos podem ser de índole subjetiva (há um direito subjetivo violado ou um interesse processual de um sujeito), ou objetiva (a pretensão deduzida em juízo é a de assegurar a integridade da ordem jurídica). O cidadão brasileiro, então, conta um elenco de instrumentos de controle do Estado, que não encontra similar em outros sistemas jurídicos, tais como as ditas "ações constitucionais" que, são, à exceção do Mandado de Injunção, instrumentos de controle da Administração, os instrumentos processuais de controle difuso e concreto de constitucionalidade (mais precisamente o recurso extraordinário) e as várias ações diretas de controle concentrado e abstrato de constitucionalidade, quase todas elas, de natureza declaratória.

De outra parte, considerando a adoção de modos contraditórios de controle de constitucionalidade, há o esforço da comunidade jurídica em aproximar os dois sistemas clássicos (difuso e concentrado). A reforma constitucional de 2004 e a Lei 11.418/06 foram promulgadas com essa finalidade. Contudo, contradições e incongruências permanecem, tais como a admissão de recurso extraordinário na ação direta de lei estadual ou municipal frente à Constituição Estadual (porque transforma o feito em ação direta frente à Constituição Federal, em razão da diversa causa de pedir) e a exigência de formulação de preliminar formal de repercussão geral nos recursos extraordinários propostos em tais ações. O melhor seria, a manter-se esta sistemática, é que os recursos extraordinários em controle concentrado de constitucionalidade fossem interpostos ex officio pelo Tribunal, em decisão que julgasse procedente a $A D I n$.

Isso é assim porque a hipótese de dispensar a preliminar formal de repercussão geral em recursos extraordinários interpostos em ação direta de constitucionalidade - deve ser elaborada pelo STF em consideração à particular singularidade de tais ações. É essencial que exista construção jurisprudencial, isto é, modificação e retificação da interpretação que se reconhece inaceitável. Assim, a Lei no 11.418/06 (Lei Processual) deverá ser interpretada (com vistas à adequada aplicação) de acordo com a racionalidade própria ao controle abstrato de normas. Este é o significado objetivo do desenvolvimento judicial do Direito - direito dos juristas.

\section{REFERÊNCIAS}

ARENDT, Hannah. Da revolução. São Paulo: Ática, 1990.

BAETHGEN Walter: Teoria geral do processo: a função jurisdicional. Porto Alegre: Editora da UFRGS, 1982.

BAPTISTA DA SILVA, . Ovídio. Curso de processo civil. 2. ed. Porto Alegre: Sérgio Antonio Fabris Editor, 1991. v. I.

BARACHO, José Alfredo de Oliveira. Aspectos da teoria geal do processo constitucional: teoria da separação de poderes e funções do Estado. Revista de Informação Legislativa, Brasília: Senado Federal, Subsecretaria de Edições Técnicas, ano 19, n. 76, 1982.

BARZOTTO, Luis Fernando. Teoria da constituição. Anotações de aula. Porto Alegre: PUCRS, 2003.

BOBBIO, Norberto. Liberalismo e democracia. São Paulo: Brasiliense, 1988.

BRASIL. Lei 221/1894.

CAPELLETTI Mauro. La jurisdiccion constitucional de la libertad. Mexico: Imprenta Universitaria, 1961. (Tradução mexicana de: $L a$ giurisdizione costituzionale delle libertà).

CLÈVE, Clemerson Mèrlin. A fiscalização abstrata de constitucionalidade no direito brasileiro. São Paulo: Editora Revista dos Tribunais, 1995.

COUTO E SILVA, Almiro. Ação direta de inconstitucionalidade de Lei Estadual ou Municipal frente à Constituição Estadual. Repensando o cabimento do recurso extraordinário. Revista da AJURIS, ano XXXIV, n. 107, p. 9-17, set. 2007. 
COUTO E SILVA, Almiro. Os indivíduos e o Estado na realização de tarefas públicas. In: BANDEIRA DE MELO, Celso Antonio (Org.). Direito administrativo e constitucional: estudos em homenagem a Geraldo Ataliba. São Paulo: Malheiros, 1997

CRUZ E TUCCI, José Rogério. Anotações sobre a repercussão geral como pressuposto de admissibilidade do recurso extraordinário (Lei 11.418/2006). Revista de Processo, São Paulo, ano 32, mar. 2007. DI PIETRO, Maria Sylvia. Direito administrativo. 2. ed. São Paulo: Atlas, 1991.

DWORKIN, Ronald. Los derechos en serio. Barcelona: Ariel, 1999.

Uma questão de princípio. São Paulo: Martins Fontes, 2000.

HAMILTON, Alexander, MADISON, James, JAY, John. O Federalista. São Paulo: Abril Cultural, 1979. (Coleção Os Pensadores).

HECK, Luís Afonso. O tribunal constitucional federal e o desenvolvimento dos princípios constitucionais. Contributo para uma compreensão da jurisdição constitucional Alemã. Porto Alegre: Sérgio Antonio Fabris Editor, 1999.

HESSE, Konrad. Elementos de direito constitucional da República Federal da Alemanha. Porto Alegre: Sérgio Fabris Editor, 1998. (Tradução da 20. ed. alemã de: Grundzüge des Verfassungsrechts der Bundesrepublik Deutschland por Luís Afonso Heck).

KELSEN, Hans. Teoria pura do direito.4. ed. Coimbra: Arménio Amado, 1979. (Tradução portuguesa de: Reine Rechtslehre, por João Baptista Machado).

Jurisdição constitucional. São Paulo: Martins Fontes, 2003. (Tradução brasileira de Verfassungs-und Vwewaktungsgerichtsbarbeikt im Dienste des Budesstates ..., por Alexandre Krug (alemão), Eduardo Brandão (italiano) e Martin Ermantina Galvão (francês). Revisão Técnica de Sérgio Servulo da Cunha).

KIMMINICH, Otto. A jurisdição constitucional e o princípio da divisão de poderes. Brasília: Revista de Informação Legislativa, Senado Federal - Subsecretaria de Edições Técnicas, n. 105, jan./mar. 1990

LAUBADÈRE, André de. Traité de droit administratif. 7. ed. Paris: L.G.D.J., 1976. t. I.
MALBERG, R. Carré de. e Contribution à la théorie générale de l'État. Paris: Sirey, 1922.

MEIRELLES, Hely Lopes et alli. Mandado de segurança e ações constitucionais. 32. ed. São Paulo: Malheiros, 2009.

MENDES, Gilmar Ferreira. Controle de constitucionalidade. Aspectos Juridicos e políticos. São Paulo: Saraiva, 1990.

Jurisdição constitucional. 5. ed. São Paulo: Saraiva, 2005.

MERKL, Adolf. Teoría general del derecho administrativo. Madrid: Editorial Revista de Derecho Privado, 1935.

MIRANDA, Jorge. Funções, órgãos e actos do estado. Apontamento de lições. Lisboa: Faculdade de Direito da Universidade de Lisboa, 1990. 2002

Teoria do estado e da constituição. Rio de Janeiro: Forense,

OLIVEIRA, Carlos Alberto Álvaro. Jurisdição e administração (notas de direito brasileiro e comparado). Cadernos de Direito Constitucional e Ciência Politica, n. 5. São Paulo: Revista dos Tribunais, out./dez. 1993.

PONTES DE MIRANDA, Francisco Cavalcanti. Comentários à Constituição de 1967. Com a Emenda $\mathrm{n}^{\circ}$ 1, de 1969. São Paulo: Editora RT, 1970. Tomo I.

Comentários ao código de processo civil. Rio de Janeiro: Forense, 1974. Tomo I.

PROCURADORIA GERAL DO MUNICÍPIO DE PORTO ALEGRE. Parecer n ${ }^{\circ}$ 1109/2004.

SATTA, Salvatore. Enciclopedia del diritto. Milão: Giuffrè, 1964. Vol. XIX. Verbete: "Giurisdizione (nozione generali)".

SEABRA FAGUNDES, Miguel. O contrôle dos atos administrativos pelo Poder Judiciário. 4. ed. Rio de Janeiro: Forense, 1967.

SOUZA JUNIOR, Cezar Saldanha. O Tribunal Constitucional como poder: uma nova teoria da divisão dos poderes. São Paulo: Memória Jurídica, 2002.

XAVIER, Alberto. Do procedimento administrativo. São Paulo: Bushatsky, 1976.

\section{NOTAS}

1 Mestre e Doutora em Teoria do Estado e do Direito pela UFRGS Especialista em Gestão Tributária pela Universidad Castilla La-Mancha. Professora de Direito Constitucional na PUCRS e na Escola Superior de Direito Municipal (ESDM). Professora de História do Direito e de Direito Municipal na Fundação Ministério Público (FMP). Procuradora do Município de Porto Alegre.

2 Como concretização do poder político, a expressão "função do Estado" desdobra-se em dois sentidos possíveis, relacionados ambos com o sentido originário da expressão 'função': função como tarefa ou incumbência em que o elemento finalístico se manifesta diretamente ou como atividade na qual a finalidade se manifesta indiretamente. $\mathrm{Na}$ primeira acepção, é tarefa ou incumbência (encargo) correspondente a certa necessidade coletiva, uma finalidade do Estado, que se concretiza em certa época histórica, traduzindo um determinado vínculo entre a sociedade e o Estado, e "um princípio (ou uma tentativa) de legitimação do exercício do poder. Alargando-se o espectro das necessidades humanas coletivas, as funções-tarefas assumidas pelo Estado são cada vez mais complexas: vão desde a garantia da segurança e da paz civil até à promoção do bem-estar e da justiça social. As chamadas 'funçõesatividades' do Estado, a seu turno, constituem meios para atingir aquelas 'funções-finalidades' previamente determinadas, são conhecidas através da análise da obra do Estado, de seus órgãos, agentes e serviços e dependem das normas constitucionais concernentes à organização do poder político principalmente as normas de fixação e repartição de competência dos órgãos estatais. Cf. MIRANDA, Jorge. Funções, írgãos e actos do estado. (Apontamento de lições). Lisboa: Faculdade de Direito da Universidade de Lisboa, 1990, p. 4.

3 Cf.. COUTO E SILVA, Almiro. Ação Direta de Inconstitucionalidade de Lei Estadual ou Municipal frente à Constituição Estadual. Repensano o cabimento do Recurso Extraordinário. Revista da AJURIS, ano XXXIV, n. 107 , p. $9-17$, set. 2007

4 A Constituição republicana ,de 1891, adotou explicitamente não só o modelo norte-americano de Estado - o Estado Federal - como também introduziu o sistema de jurisdição única, de feição inglesa, para o controle jurisdicional da Administração Pública. Pelo sistema de jurisdição única, as autoridades judiciárias conhecem de quaisquer ações, independentemente de estas se terem originado ou não em atos da Administração Pública. Neste particular, ressalta Seabra Fagundes que, "nos países de regime presidencial, como o nosso, ficando o Executivo, praticamente, acima das intervenções do Parlamento, que só de modo indireto e remoto influi na sua ação e a fiscaliza, cresce de importância a interferência jurisdicional, no exame da atividade administrativa". Ver: SEABRA FAGUNDES, Miguel. O contrôle dos atos administrativos pelo Poder Judiciário. 4. ed. Rio de Janeiro: Forense, 1967, p. 113.

5 Cf. MERKL, Adolf. Teoría general del derecho administrativo. Madrid: Editorial Revista de Derecho Privado, 1935, p. 228 e KELSEN, Hans. Teoria pura do direito. 4. ed. Coimbra: Arménio Amado, 1979. (Tradução portuguesa de Reine Rechtslehre, por João Baptista Machado, p. 267-374.

6 Para Chiovenda, a jurisdição é função do Estado, que tem por finalidade a atuação da vontade concreta da lei mediante a substituição, pela atividade dos órgãos públicos, da atividade dos particulares ou de outros 
órgãos públicos. Para Calamandrei, dois são os caracteres essencias da jurisdição: uma atividade de substituição e uma atividade declarativa; já Allorio atribui à coisa julgada o sinal característico da jurisdição. Carnelutti entende por jurisdição a atividade voltada à composição da lide, com imparcialidade (regulação de uma relação interpessoal por um terceiro imparcial). Cf. Ovídio Baptista da Silva. Curso de processo civil. 2. ed. Porto Alegre: Sérgio Antonio Fabris Editor, 1991, v. I, p. 17-28.

7 SATTA, Salvatore. Enciclopedia del diritto. Milão: Giuffrè, 1964, v. XIX, verbete "Giurisdizione (nozione generali)", p. 218 e ss.

8 Cf. SATTA, cit., idem.

9 Para Walter Baethgen, a resolução de conflitos intersubjetivos supondo-se seja esta a finalidade da jurisdição - envolve a necessidade de visualizar-se o problema sob dois aspectos: a) o plano abstrato, que é o plano da norma jurídica (atividade legislativa ou de outras fontes), propondo uma solução de comportamento futuro, e b) o plano da concreção da norma abstrata, em que a sentença realiza a "norma do caso", da mesma forma que também o fazem o "negócio jurídico privado" e o "ato administrativo". In: Teoria geral do processo: a função jurisdicional. Porto Alegre: Editora da UFRGS, 1982, p. 34-36.

10 PONTES DE MIRANDA, Francisco Cavalcanti. Comentários à Constituição de 1967. Com a Emenda n ${ }^{\circ} 1$, de 1969. São Paulo: Editora RT, 1970, t. I, p. 156 e Comentários ao código de processo civil, Rio de Janeiro: Forense, 1974, t. I, p. 105.

${ }^{11}$ Cf. PONTES DE MIRANDA, Comentários à Constituição..., cit., p. 107. No texto, o autor aponta outros modos de extinção da dívida jurisdicional: conciliação das partes; homologação da transação; perempção da instância devida à inatividade processual, sem que se extinga a ação e o direito; desistência de direito processual ou renúncia formal, "inconfundível com a renúncia de direito material ou simplesmente renúncia material".

${ }^{12}$ Cf. XAVIER, Alberto. Do procedimento administrativo. São Paulo: Bushatsky, 1976, p. 30

${ }_{13}$ Cf. SATTA, cit., p. 224

${ }^{14}$ Cf. LAUBADĖRE, André de. Traité de droit administratif. 7. ed. Paris: L.G.D.J., 1976, t. I, p. 235.

15 Cf. MALBERG, R. Carré de. e Contribution à la théorie générale de l'État. Paris: Sirey, 1922, t. I, p. 785.

16 SEABRA FAGUNDES, cit., p. 25-26.

${ }^{17}$ SEABRA FAGUNDES, cit., p. 28.

${ }^{18}$ SEABRA FAGUNDES, cit., p. 86. No texto consultado, Seabra Fagundes pondera que a sentença normativa da Justiça do Trabalho, quando estende a decisão aos demais empregados que forem da mesma profissão dos dissidentes (art. 868 da CLT), é de natureza mista: "jurisdicional, enquanto resolve o conflito suscitado, e legislativo, quando obriga a terceiros que não invocaram a Justiça" (p. 95).

19 SEABRA FAGUNDES, cit., p. 35.

${ }^{20}$ Cf. MIRANDA, Jorge, cit., p. 21 e SEABRA FAGUNDES, cit. p. 86-94.

${ }^{21}$ PONTES DE MIRANDA, Comentários à Constituição ..., cit., t. III, p. 269.

${ }^{22}$ Nesse passo, cabe ressaltar ainda a posição de Alberto Xavier, segundo a qual o ato administrativo se distingue do ato jurisdicional porque este último tem "como causa típica a declaração de certeza de situações individuais", isto é, é a sua finalidade; o ato administrativo, ainda que envolva, em sua edição, a aplicação da lei e, por conseguinte, um momento cognoscitivo, a certeza por ele criada não é sua finalidade, sendo apenas um meio para a consecução de seus fins peculiares. Tal diferença se revela quando ocorre o silêncio da Administração Pública, pois, quando esta tem a obrigação de se pronunciar e não o faz, o silêncio vale como ato jurídico, isto é, produz efeitos jurídicos que se tornam imutáveis, a menos que sejam impugnados pela via contenciosa. $\mathrm{Na}$ Jurisdição, esta situação é inimaginável: "o silêncio dá apenas origem a uma infração ou à responsabilidade civil, sem que dele seja possível extrair uma decisão fictícia. É justamente no aspecto 'formação de coisa julgada' ou 'declaração de certeza', que se avizinha a concepção da jurisdição voluntária (a que Alberto Xavier prefere chamar de jurisdição graciosa) como 'tutela jurídica administrativa', pois, nesses processos, visa-se obter "um tipo de tutela que não consiste na declaração autoritária e definitiva de certeza em que a coisa julgada se traduz.". A estrutura do processo na Jurisdição Voluntária, não é, por conseguinte, triangular, mas bilateral, existindo somente a relação entre o peticionante e o Estado, mesmo que, no feito, terceiros possam intervir. Aos intervenientes, nestes processos, não se dá a qualificação de 'partes' porque contra eles não é formulada nenhuma pretensão de fundo. In: op. cit., p. 71 e ss.

${ }^{23}$ Cf. MIRANDA, Jorge. Teoria do Estado e da Constituição. Rio de Janeiro: Forense, 2002, p. 481.
${ }^{24}$ Heck esclarece que, no sentido formal, a jurisdição constitucional se define a partir do órgão que a exerce; no sentido material, a jurisdição constitucional "pode ser compreendida a partir do procedimento judiciário (ou arbitral), o qual conduz ao controle de constitucionalidade, objetivando garantir diretamente a observância da Constituição." Nos dois casos, não é absolutamente correto afirmar que a raiz da jurisdição constitucional é a experiência norte-americana, uma vez que, na Alemanha, de há muito, já havia a prática do direito ao exame judicial. Reconhece ele, contudo, que o desenvolvimento e a consequente consolidação do direito ao exame judicial vinculado à teoria do contratualismo e à existência de uma constituição deu-se a partir da decisão Marbury v. Madison, da Suprema Corte, em 1803. In: HECK, Luís Afonso. O tribunal constitucional federal e o desenvolvimento dos princípios constitucionais. Contributo para uma compreensão da Jurisdição Constitucional Alemã. Porto Alegre: Sérgio Antonio Fabris Editor, 1995, p. 23-24 e 30.

${ }^{25}$ KELSEN, Hans. Jurisdição Constitucional. São Paulo: Martins Fontes, 2003. Tradução brasileira de Verfassungs-und Vwewaktungsgerichtsbarbeikt im Dienste des Budesstates ... por Alexandre Krug (alemão), Eduardo Brandão (italiano) e Martin Ermantina Galvão (francês). Revisão Técnica de Sérgio Servulo da Cunha.

${ }^{26}$ KELSEN, cit., p. 18, verbis: "Entre a jurisdição constitucional e a administrativa existe uma distinção teórico-jurídica fundamental, que justifica também uma diferenciação técnico-jurídica das duas funções. Trata-se da distinção entre a constitucionalidade dos atos jurídicos, e sua mera conformidade às leis. Essa diferença naturalmente pressupõe a existência de uma Constituição no sentido formal, ou seja, de normas particularmente qualificaadas com respeito à formação e modificação daqueles atos."

${ }^{27}$ KELSEN, cit., p. 19

${ }^{28}$ In: Teoria do Estado ..., cit., p. 498.

${ }^{29}$ In: Teoria do Estado ..., cit., p. 498.

${ }^{30}$ BARACHO, José Alfredo de Oliveira. Aspectos da teoria geal do processo constitucional: teoria da separação de poderes e funções do Estado. Revista de Informação Legislativa, Brasília: Senado Federal, Subsecretaria de Edições Técnicas, ano 19, n. 76, p. 101, 1982.

${ }^{31}$ Cf. BARACHO, cit., p. 101.

${ }^{32}$ Cf. CAPELLETTI Mauro. La jurisdiccion constitucional de la libertad. Mexico: Imprenta Universitaria, 1961, p. 5. Tradução mexicana de $L a$ giurisdizione costituzionale delle libertà.

33 Cf. BARACHO, cit., p. 102.

${ }^{34}$ Neste aspecto, ver tese de livre docência de Cezar Saldanha, segundo a qual o Tribunal Constitucional é um sexto poder, in: SOUZA JÚNIOR, Cezar Saldanha. O Tribunal Constitucional como Poder. Uma nova teoria da divisão dos poderes. São Paulo:Memória Jurídica, 2002.

35 Segundo Kimminich, nos termos da Lei Fundamental e da Lei do Bundesverfassungsgericht (Tribunal Constitucional Federal), os processos através dos quais se controla constitucionalidade são: a) controle abstrato, mediante requerimento do Governo Federal a um Governo estadual ou de 1/3 dos membros do parlamento Federal; b) controle concreto, mediante um requerimento de um tribunal que considera a lei inconstitucional e deve aplicá-la a um recurso pendente; c) recurso constitucional, que pode ser impetrado por qualquer pessoa sob a alegação de violação ou ofensa a direito fundamental; d) recurso constitucional dirigido indiretamente contra um ato normativo, que impugna diretamente uma decisão judicial, mas, indiretamente, volta-se contra a norma que lhe empresta sustentação. KIMMINICH, Otto. A jurisdição constitucional e o princípio da divisão de poderes. Brasília: Revista de Informação Legislativa, Senado Federal - Subsecretaria de Edições Técnicas, n. 105, p. 286, jan./mar. 1990.

${ }^{36}$ Cf. KIMMINICH, cit., p. 285-286.

37 KIMMINICH, cit., p. 292.

${ }^{38}$ HESSE, Konrad. Elementos de Direito Constitucional da República Federal da Alemanha. Porto Alegre: Sérgio Fabris Editor, 1998, p. 376. Tradução da 20. ed. alemã de Grundzüge des Verfassungsrechts der Bundesrepublik Deutschland por Luís Afonso Heck.

${ }^{39}$ HESSE, cit., p. 419.

40 Das inovações trazidas pela Revolução Americana, talvez a mais importante tenha sido o estabelecimento de uma instituição concreta destinada ao exercício da autoridade (que não se assenta nas leis e sim na tradição): o ramo judiciário do governo. No modelo romano copiado pelos pais fundadores, o poder estava no povo e a autoridade (auctoritas), em uma instituição política - o Senado - . Os fundadores, entretanto, ao mudarem a localização da autoridade, compreenderam que a sua majestade nacional se manifestava através das cortes de justiça e que esta tornava o Judiciário inadequado para o poder da mesma forma que, 
em sentido inverso, o poder legislativo tornava o Senado(americano) impróprio para o exercício da autoridade. Assim, foi precisamente a falta de poder e a permanência no cargo que transformou a Suprema Corte americana na verdadeira sede da autoridade, exercida através de uma contínua formulação da Constituição. A flexibilização constitucional, assim, é feita por juízes, já que tal faculdade não é dada ao Congresso, e o staff jurídico constitui, efetivamente, uma espécie de "classe politica superior". A partir daí, a Suprema Corte tornou-se, de fato, "uma espécie de assembleia constitucional em sessão permanente", instituindo o controle judicial formal de constitucionalidade, "a única contribuição da América à ciência do governo".Com base nestas premissas, Grant sustentou a tese de que o controle jurisdicional da constitucionalidade das leis - judicial review of legislation - foi, efetivamente, uma contribuição da América à Ciência Política, uma vez que "a confiança nos tribunais para fazer cumprir a Constituição como norma superior às leis estabelecidas na legislatura nacional se operou graças ao seu surgimento ali, realizado no séc. XVIII, para difundir-se posteriormente em outros Estados. Ver: Woodrom WILSON, como citado por CORWIN, Edward, in: The "Higher Law" background of American Constitutional Law, Harvard Law Review, v. 42, 1928, p. 3, apud ARENDT, Hannah. Da revolução. São Paulo: Ática, 1990, p. 161; MADISON, James, $n^{\circ}$ L in: HAMILTON, Alexander, MADISON, James, JAY, John. O Federalista. Coleção "Os Pensadores". São Paulo: Abril Cultural, 1979, p. 98; GRANT, James. A. C. El Control Jurisdicional de la Constitucionalidad de las Leyes. Una Contribución de las Américas a la Ciencia Politica. México: Facultad de Derecho de la UNAM, 1963, apud BARACHO, cit., p. 99; BARZOTTO, Luis Fernando. Teoria da Constituição. Anotações de aula. Porto Alegre: PUCRS, 2003.

${ }^{41}$ Ver, artigos 13, caput e $\S 9^{\circ}$, letras "a" e "b", e $\S 10$, da Lei 221, verbis: Art. 13. "Os juizes e tribunaes federaes processarão e julgarão as causas que se fundarem na lesão de direitos individuaes por actos ou decisão das autoridades administrativas da União"; § $9^{\circ}$ "Verificando a autoridade judiciaria que o acto ou resolução em questão é illegal, o annullará no todo ou em parte, para o fim de assegurar o dieito ao autor: a) Considerando illegaes os actos ou decisões administrativas em razão da não applicação ou indevida applicação do direito vigente. A autoridade judiciaria fundar-se-há em razões juridicas, abstendo-se de apreciar o merecimento de actos administrativos, sob o ponto de vista de sua conveniencia ou opportunidade; b) A medida administrativa tomada em virtude de uma faculdade ou poder discricionário sómente será havida por illegal em razão de incompetencia da autoridade respectiva ou do excesso de poder." $\S 10^{\circ}$ - "Os juizes e tribunaes apreciarão a validades das leis e regulamentos e deixarão de applicar aos casos occurrentes as leis manifestamente inconstitucionaes e os regulamentos manifestamente incompativeis com as leis ou com a Constituição."

${ }^{42}$ Cf. CAIO TÁCITO, p. 15 e OLIVEIRA, Carlos Alberto Álvaro. Jurisdição e Administração (notas de direito brasileiro e comparado). Cadernos de Direito Constitucional e Ciência Política, São Paulo: Revista dos Tribunais, n. 5, p. 40, out./dez. 1993.

${ }^{43}$ CF. COUTO E SILVA, Almiro. Os indivíduos e o Estado na realização de tarefas públicas. In: BANDEIRA DE MELO, Celso Antonio (org.). Direito Administrativo e Constitucional: estudos em homenagem a Geraldo Ataliba. São Paulo: Malheiros, 1997.

${ }^{44}$ Cf. SEABRA FAGUNDES, p. 115 e ss.

${ }^{45}$ DI PIETRO, Maria Sylvia. Direito Administrativo. 2. ed. São Paulo: Atlas, 1991, p. 165.

${ }^{46}$ COUTO E SILVA, cit., p. 24. No texto, o autor explica que até a Constituição de 1946, que instituiu a ação popular, a defesa do interesse público se dava de forma indireta, pela defesa de direitos subjetivos lesados ou ameaçados de lesão. Era o sistema que Duguit chamou de "contencioso subjetivo".

${ }^{47}$ COUTO E SILVA, cit., p. 25.

48 PONTES DE MIRANDA, Comentários ao Código de Processo..., cit., p. 46.

${ }^{49}$ Cf. BARZOTTO, cit.

${ }^{50}$ MIRANDA, Jorge. Teoria da Constituição..., cit., p. 532.

$51 \mathrm{O}$ pressuposto filosófico do Estado Liberal [...] é a doutrina dos direitos do homem elaborada pelo jusnaturalismo. [...] Todos os homens têm por natureza e, portanto, independentemente de sua própria vontade [...] certos direitos fundamentais como o direito à vida, à liberdade, à segurança $\mathrm{e}$ à felicidade",assevera Bobio. Segundo Dowrkin, o liberalismo defende que as pessoas possuem "direitos que são naturais, no sentido de que não são produto de nenhuma legislação, convenção ou contrato hipotético." Assim, os direitos não são produtos de um ato legislativo ou mesmo de um costume explícito, mas "constituem fundamentos independentes para julgar a legislação e os costumes" e, ademais disso, são exercidos contra os demais. Dworkin ainda percebe a centralidade dos direitos na experiência jurídico-política americana, verbis: "O debate público nos Estados Unidos é dominado [...] pela discussão de que direitos as pessoas têm. Na Grã-Bretanha, o debate político está centrado na ideia [... de bem-estar geral ou bem coletivo.” Daí que, naquele país, a justiça seja uma questão de direito individual e não uma questão de bem público. Ver: BOBBIO, Norberto. Liberalismo e democracia. São Paulo: Brasiliense, 1988, p. 11; DWORKIN, Ronald. Los derechos en serio. Barcelona: Ariel, 1999, p. 267 e 269 e Uma questão de princípio. São Paulo: Martins Fontes, 2000, p. 37.

${ }^{52}$ BOBBIO, cit., p. 19

${ }^{33}$ Cf. MIRANDA, Jorge. Teoria da Constituição ..., cit., p. 532.

${ }^{54} \mathrm{Em}$ decisões envolvendo a progressividade do ITBI, o Supremo Tribunal Federal expressamente determinou que, em razão do decreto de inconstitucionalidade das alíquotas progressivas, fosse aplicada ao autor da demanda, para fixação da alíquota, a legislação anterior que, pela inconstitucionalidade da posterior, nunca fora validamente revogada. Tais decisões foram proferidas nos RE 259.339-7, 264.803-5 e 260.670-7. No RE 259-339-7 ( ${ }^{\text {a }}$ Turma do STF, unânime, relator o Ministro Sepúlveda Pertence, julgado em 09/05/2000, publicado no DJU, Seção I, de 16/06/2000), constou, na ementa, o seguinte: "EMENTA - ITBI: progressividade: L. 11.154/91, do Município de São Paulo: inconstitucionalidade. A inconstitucionalidade, reconhecida pelo STF (RE 234.105), do sistema de alíquotas progressivas do ITBI do Município de São Paulo (L. 11.514/91, art. 10, II), atinge esse sistema como um todo, devendo o imposto ser calculado, não pela menor das alíquotas progressivas, mas na forma da legislação anterior, cuja eficácia, em relação às partes, se restabelece com o trânsito em julgado da decisão proferida neste feito." O voto do Sr. Ministro Relator destaca: "Disso não resulta, no entanto, a possibilidade de deferir-se a segurança como requerida, isto é, para reconhecer à impetrante o direito de recolher o ITBI calculado pela menor das alíquotas previstas no citado dispositivo, o que implicaria em fazer incidir, entre a lei anterior e a subsequente, declarada inconstitucional, uma terceira que jamais existiu, a que estabelece alíquota única para o tributo, equivalente à menor das previstas no escalonamento que - dado o critério progressivo - se reputou vedado pela Constituição. Tal como declarada pelo Plenário, a inconstitucionalidade atinge o sistema da progressividade como um todo, da menor à maior alíquota, devendo ser calculado o imposto na forma da legislação anterior, cuja eficácia, em relação às partes, se restabelece com o trânsito em julgado da decisão proferida neste feito.

${ }^{55}$ CLÈVE, Clemerson Mèrlin. A Fiscalização Abstrata de Constitucionalidade no Direito Brasileiro. São Paulo: Editora Revista dos Tribunais, 1995, p. 167.

${ }^{56}$ EMENTA: INCONSTITUCIONALIDADE DE LEI MUNICIPAL INTERPRETAÇÃO E CONCREÇÃO DA CONSTITUIÇÃO PELA ADMINISTRAČ̃̃O PÚBLICA - POSSIBILIDADE DE O EXECUTIVO MUNICIPAL DECLARAR A INEFICÁCIA DE LEI VÁLIDA NO ÂMBITO DO MUNICÍPIO - ADEQUAÇÃO DA ADMINISTRAÇÃO AO PRINCÍPIO DA LEGALIDADE FORMAL (RESERVA DE LEI) - ORIENTAÇÃO PELO PRECEITO DA PROPORCIONALIDADE EXIGÊNCIA DE ANULAÇÃO DE ATO ADMINISTRATIVO EMITIDO COM BASE EM LEI RECONHECIDAMENTE INCONSTITUCIONAL - EFEITOS JURÍDICOS E LEGAIS. PARECER N ${ }^{\circ} 1109 / 2004$, da Procuradoria-Geral do Município de Porto Alegre, da lavra de Maren Guimarães Taborda, Gamaliel Valdovino Borges e Marcelo Dias Ferreira, exarado em 22 de dezembro de 2004. Disponível in: <http://www. portoalegre.rs.gov.br>. Acessado em: 14 jan. 2010.

${ }^{57}$ De acordo com Cezar Saldanha Souza Jr., aí reside justamente um dos problemas da ordem institucional brasileira, porque, ao se distanciar da tradição jurídica da Europa continental, o legislador constituinte brasileiro acabou criando um sistema em que há acúmulo e concentração de poder, na medida em que, no Brasil, não se faz a separação entre Governo, Administração e Jurisdição Constitucional. In: SOUZA JUNIOR, O Tribunal Constitucional ..., cit., passim.

${ }^{58}$ Como acentua Heck, Tribunal Constitucional em sentido estrito é órgão instituído pela própria Constituição, com competências previamente estabelecidas no texto constitucional e que compartilha, "em forma decisiva, da formação política global do Estado", cit., p. 102.

59 Site oficial do Supremo Tribunal Federal: <www.stf.gov.br>. Acessado em: 03 mar. 2009.

${ }^{60}$ CRUZ E TUCCI, José Rogério. Anotações sobre a repercussão geral como pressuposto de admissibilidade do recurso extraordinário (Lei 11.418/2006). Revista de Processo, São Paulo: Editora RT, ano 32, p. 153 , mar. 2007. 
${ }^{61}$ José Miguel Garcia Medina, Luiz Rodrigues Wambier e Teresa Arruda Alvim. Repercussão geral e súmula vinculante. $A$ EC $n .45$ e o instituto da repercussão geral, Reforma do Judiciário (obra coletiva). São Paulo: RT, 2005, apud TUCCI, cit., p. 153.

${ }^{62}$ Matérias com mérito da Repercussão Geral julgado:; 1. Competência. Justiça do Trabalho e Justiça Estadual. Art. 114, I E IX Da CF. Decisão sobre forma de pagamento dos créditos previstos no quadro geral de credores e no plano de recuperação Judicial. Vrg Linhas Aéreas S/A. Recuperação judicial e falência. Lei 11.101/2005; 2. Compensação de prejuízos e Lei 8.981/95; 3. Auxílio-reclusão e renda bruta do segurado preso; 4. Mandado de segurança. Cabimento. Impetração de mandado de segurança contra decisão de juiz de juizado especial que defere liminar; 5. Gratificação: Dispensa de avaliação e extensão aos inativos; 6. Previdenciário. Cálculo de aposentadoria e impossibilidade da adoção de sistema híbrido; 7. Isenção de cofins e revogação por lei; 8. ISS. Incidência. Arrendamento mercantil. Leasing; 9. ICMS. Alíquota. Lei estadual que prorroga majoração de alíquota estabelecida em lei anterior. Proibição de vinculação de receita de impostos. Art. 167, IV da CF. Leis 9.903/97 e 10.136/98 de São Paulo, entre outras. Informação disponível em: < http://www.stf.gov.br>.

${ }^{63}$ Em 1934, o Deputado Federal Nilo Alvarenga propôs a instituição de uma Corte Constitucional, diretamente inspirado por Kelsen. Não havendo vingado essa proposta, só com a Emenda 16/65 é que se passou a admitir a possibilidade de se outorgar a órgão do Ministerio Público a iniciativa do controle de constitucionalidade in abstracto. Para esse itinerário, ver: MENDES, Gilmar Ferreira. Jurisdição Constitucional. 5. ed. São Paulo: Saraiva, 2005, p. 64 e ss; MENDES, Gilmar Ferreira.
Controle de Constitucionalidade. Aspectos Juridicos e políticos. São Paulo: Saraiva, 1990, p. 169 e ss; MEIRELLES, Hely Lopes, et alli. Mandado de Segurança e ações constitucionais. 32. ed. São Paulo: Malheiros, 2009, p. 330 e ss. (capítulo de autoria exclusiva de Gilmar Ferreira Mendes).

64 MENDES, Gilmar, in: Mandado de Segurança ..., cit., p. 334.

$65 \mathrm{O}$ inteiro teor dos Acórdãos da $\mathrm{ADC} \mathrm{n}^{\circ}$ 5-2, Distrito Federal e da $\mathrm{ADC} /$ $\mathrm{MC} \mathrm{n}^{\circ} 8$, foram recolhidos do sítio oficial do STF na web: $<$ http://stf.gov. br>, acessado em: 12 jan. 2010.

66 MENDES, Gilmar. Mandado de Segurança ..., cit., p. 543.

${ }^{67}$ MENDES, Gilmar. Mandado de Segurança ..., cit., p. 543.

68 O Acórdão, publicado no sítio oficial do STF na web, com mais de 300 páginas, constitui um "verdadeiro tratado" de direito constitucional, de leitura imprescindível para todos os cultores e estudiosos do Direito Constitucional. Acessado em: 15 out. 2009.

69 MENDES, Gilmar. Mandado de Segurança ..., cit., p. 544.

70 Ver MIRANDA, Jorge. Teoria da Constituição ..., cit., p. 532.

71 COUTO E SILVA, Almiro. Ação Direta de Inconstitucionalidade ..., cit., p. 10 e p. 17

${ }^{72}$ COUTO E SILVA, Almiro. Ação Direta de Inconstitucionalidade ..., cit., p. 11.

73 COUTO E SILVA, Almiro. Ação Direta de Inconstitucionalidade .., cit, p. 12.

74 Ibidem.

75 Ibidem.

${ }^{76}$ Min. Nelson Jobim. $A D C$ 4-6 DF, Julgamento 11/01/1998. Íntegra do Acórdão. Disponível em: <http://stg.gov.br>. Acessado em: 10 maio 2009. 